NBER WORKING PAPER SERIES

\title{
LEAD WATER PIPES AND INFANT MORTALITY IN TURN-OF-THE-CENTURY MASSACHUSETTS
}

\author{
Werner Troesken \\ Working Paper 9549 \\ http://www.nber.org/papers/w9549 \\ NATIONAL BUREAU OF ECONOMIC RESEARCH \\ 1050 Massachusetts Avenue \\ Cambridge, MA 02138 \\ March 2003
}

This research has been supported by a grant from the NIA, AG10120-09A1. Claudia Linares and Paula Canavese provided research assistance at an early stage of this project. The views expressed herein are those of the authors and not necessarily those of the National Bureau of Economic Research.

(C)2003 by Werner Troesken. All rights reserved. Short sections of text not to exceed two paragraphs, may be quoted without explicit permission provided that full credit including Cnotice, is given to the source. 
Lead Water Pipes and Infant Mortality in Turn-of-the-Century Massachusetts

Werner Troesken

NBER Working Paper No. 9549

March 2003

JEL No. I1, J1, N3

\title{
$\underline{\text { ABSTRACT }}$
}

This paper considers a largely unknown public-health practice in the United States: the use of lead pipes to distribute household tap water. Municipalities first installed lead pipes during the late nineteenth century. In 1897, about half of all American municipalities used lead water pipes. Using data from 1900 Massachusetts, this paper compares infant death rates and stillbirth rates in cities that used lead water pipes to rates in cities that used non-lead pipes. In the average town in 1900, the use of lead pipes increased infant mortality and stillbirth rates by 25 to 50 percent. However, the effects of lead water lines varied across cities, and depended on the age of the pipe and the corrosiveness of the associated water supplies. Age of pipe influenced lead content because, over time, oxidation formed a protective coating on the interior of pipes. As for corrosiveness, acidic water removed more lead from the interior of pipes than did non-acidic water. Consequently, infant death rates and stillbirth rates in Massachusetts towns employing old lead lines, and non-acidic water supplies, were no higher than in towns employing non-lead pipes. But in cities using new pipes and distributing acidic water, lead pipes increased infant mortality rates and stillbirth rates three- to fourfold.

\author{
Werner Troesken \\ Department of History \\ University of Pittsburgh \\ Pittsburgh, PA 15260 \\ and NBER \\ troesken@pitt.edu
}




\section{Introduction}

This paper considers an important, but largely unknown, public-health practice in the United States: the use of lead service lines to distribute household tap water. Municipalities first installed lead service lines during the late nineteenth and early twentieth century, and in some places, the original lead pipes are still in use. In 1897, about half of all municipalities had water systems based exclusively, or in part, on lead service lines; the remaining cities used iron pipes or metal pipes lined with cement. The use of lead pipes was positively correlated with city size. In 1900, the country's five largest cities-New York, Chicago, Philadelphia, Saint Louis, and Boston-all used lead pipes to varying degrees. For cities with populations greater than 30,000, more than 70 percent used lead lines exclusively or in combination with some other type of metal. ${ }^{1}$ Although it is now well known that ingesting or inhaling even small amounts of lead can have severe health effects, particularly for young children, ${ }^{2}$ little is known about the consequences of these lead water lines. ${ }^{3}$ Accordingly, this paper exploits an unusually rich set of data sources to identify the health effects of lead water pipes in turn-of-the-century Massachusetts. With these data, it is possible to compare infant death rates and stillbirth rates in cities that used lead water pipes to rates in cities that used non-lead pipes.

The central findings of the paper are as follows. In the average Massachusetts town in 1900, the use of lead pipes increased infant mortality and stillbirth rates by 25 to 50 percent. However, the effects of lead water lines varied across cities, and depended on the age of the pipe and the

${ }^{1}$ The statistics in this paragraph are based on data from Baker's Manual of American Waterworks (1897), and United States General Statistics of Cities (1902). See also, Troesken and Beeson (forthcoming).

${ }^{2}$ See, for example, Needleman and Belinger (1991).

${ }^{3}$ At present, there exists only one study of the health effects of lead pipes, and this study focuses on the experience of adults (Troesken and Beeson, forthcoming). 
corrosiveness of the associated water supplies. Age of pipe influenced water-related lead ingestion because, over time, oxidation formed a protective coating on the interior of pipes and limited the amount of lead that dissolved into the water. As for corrosiveness, acidic water removed more lead from the interior of pipes than did non-acidic water. ${ }^{4}$ Consequently, infant death rates and stillbirth rates in Massachusetts towns employing old lead lines, and non-acidic water supplies, were no higher than in towns employing iron or cement water lines. But in cities using new pipes and distributing water derived from acidic sources, lead pipes had enormous effects: they increased infant mortality rates and stillbirth rates three- to fourfold. Such estimates might sound high, but as will be made clear below, they are quite plausible when one considers just how much lead could be dissolved into household tap water as a result of lead service lines. For example, samples of household tap water in Lowell—a city that used lead pipes_contained average lead levels nearly 200 times greater than those currently allowed by the Environmental Protection Agency.

One potential concern with the estimates presented here is that they could overstate the impact of lead water mains on the probability long-term survival if lead water mains killed off only the weakest and most vulnerable of all infants. Water-related lead exposure, in other words, might have been fatal only for infants who would have inevitably succumbed to some other environmental insult or childhood disease, such as scarlet fever, diphtheria, measles, or whooping cough. Although there is evidence that water-related lead poisoning affected the most vulnerable infants disproportionately, and that the use of lead water lines actually reduced death rates for some childhood diseases, these effects were small. After controlling for this selection issue, lead water lines still appear to have had a substantial effect on infant mortality in towns with acidic water

${ }^{4}$ One how age of pipe and corrosiveness of water influences the amount of lead in drinking water, see Howard (1923); Quam and Klein (1936); United States Environmental Protection Agency (2000); Wisconsin Department of Natural Resources (1993). 
supplies, or with relatively new lead pipes.

These results are important in at least four ways. First, their magnitude is significant: a 25 to 50 percent increase in infant and fetal mortality rates is a large number. Second, the results are important because they are surprising. Noone in 1900, not even the handful of public health officials who first spoke out against the use of lead pipes, thought the adverse health effects of lead water lines were as large as the findings here suggest. ${ }^{5}$ As late as 1917, the engineers who designed urban water systems were dismissing claims that lead services could cause widespread lead poisoning, and continued to advocate the use of lead pipes because of their attractive mechanical qualities. And today, while the dangers of lead are widely appreciated, nearly all health scholars and regulators focus on other pathways of exposure, such as paint, household dust, dirt, leaded gasoline, and industrial pollution. ${ }^{6}$

Third, during the early twentieth century, the federal government, as well as many state governments, started enacting laws prohibiting and/or severely limiting the use of lead service lines and lead based solders in household plumbing. The results here suggest that the gross social benefit of such laws was very high. Although it is not possible to precisely estimate the net benefit of such laws because there are no data on the costs of enforcement and compliance, it will be made clear below, that there were low-cost substitutes for lead pipes available in 1900, notably iron and cementlined pipes. While not as malleable or as durable as lead, iron and cement-lined pipes also did not poison the water they carried. Regulations governing the use of lead in plumbing fixtures are, as

${ }^{5}$ Of course, this observation cuts both ways and might also raise doubts about the estimated effects reported here.

${ }^{6}$ On exposure pathways emphasized in recent studies, see Charney, Sayre and Coulter (1980); Lanphear and Rogham (1997); Markowitz and Rosner (2000); Trepka et al. (1997); Wolpaw Reyes (2003); and Xintaras (1992). 
regulations go, fairly obscure. There is a tendency among students of public choice to think that the more obscure the regulation, the less likely it is reflect the broader public interest, and the more likely it is to represent the lobbying of narrow special interests. ${ }^{7}$ Laws governing the use of lead pipes certainly appear to be a counter-example to this general way of thinking.

Finally and most important in terms of motivation, the early-twentieth-century United States witnessed dramatic improvements in life expectancy, particularly for urban-dwelling populations (Haines 2001). It is widely accepted that most of these improvements were driven by reductions in infant mortality, which in turn, were promoted by better nutrition and improved public health services that protected infants and young children from infectious diseases, particularly deaths from infantile diarrhea. ${ }^{8}$ This paper suggests that the latter part of this story needs to be revised: reductions in environmental lead exposure appear to have also played a significant role in promoting healthier and more robust children, who were better able to withstand the bacterial and viral insults so common in early twentieth century American cities. Of studies that look at infant mortality and mortality transitions in the United States, Preston and Haines (1991) is probably the best known and most important. In their analysis of Census data from the turn of the century, Preston and Haines emphasize the importance of infectious diseases; they, like most authorities, scarcely mention lead poisoning as a cause of infant mortality (see, generally, Preston and Haines 1991, pp. 3-48).

\section{Lead Service Lines in America: A History}

\section{A. Lead Service Lines: Why and How Many?}

Lead was often used in the construction of water service lines. Service lines were the pipes that connected individual homes and apartment buildings to street mains. Aside from lead, service

\footnotetext{
${ }^{7}$ See, for example, the analyses of Buchanan and Tullock (1962) and Downs (1957).

${ }^{8}$ Relevant citations are provided in the concluding section of the paper.
} 
lines were also made of plain iron or steel; galvanized iron or steel; and cement-lined iron. Relative to these other materials, lead had two features that made it attractive to the engineers who designed public water systems: it was both malleable and durable. Malleability reduced labor costs by making it easier to bend the service main around existing infrastructure and obstructions, and compared to iron, lead was a soft and pliable metal. As for durability, the life of the typical lead service pipe was thirty-five years. By contrast, plain iron or steel pipe lasted sixteen years; galvanized pipe twenty years; and cement lined pipe twenty-eight years. Based solely on engineering concerns, these characteristics made lead the ideal material for service lines. As one prominent trade journal wrote: "Lead is in many respects the most satisfactory material to use for service pipes. Its pliability and its comparative freedom from corrosive action make it almost ideal from a mechanical standpoint."’

The two problems with using lead were its high up-front cost and its potential toxicity. In terms of up-front cost of materials, a small iron or steel pipe that was neither galvanized nor lined was certainly cheaper than lead. But as stated above, untreated iron and steel pipes had expected life spans that were less than half that of lead pipes. Because replacing broken service mains often required digging up paved streets and working around other infrastructure such as gas and sewer mains, the costs of reduced main life overwhelmed whatever savings were generated from reduced materials costs. ${ }^{10}$ As for concerns that lead service lines might poison the water they carried, most

${ }^{9}$ Information and quotations in this paragraph come from the Engineering News, September 28, 1916, pp. 594-96 (hereafter cited as EN); and from the Committee on Service Pipes (1917), p. 328 (hereafter cited as CSP). The editors of the Engineering News were not alone in suggesting that lead, even with concerns about safety, was the best material for service lines. A survey of the superintendents of forty-one municipal water companies found that about half (20) preferred lead service lines to all other types of lines. This survey was conducted in 1884 by water industry expert from New London, Connecticut. The results were reported in the Journal of the New England Water Works Association, September, 1917, pp. 346-47.

${ }^{10}$ A prominent trade journal explained (EN, p. 595): “The cost of lead pipe of sufficient thickness to safely withstand the pressure is more than the cost of many other materials used for 
engineers appear to have believed that such concerns were overblown (EN, p. 595).

That lead worked well, from a narrow mechanical stand point, is clear when one examines how popular lead service lines were. At the turn of the twentieth century, the use of lead service mains was widespread, particularly in large cities. This can be seen in two independent samples of cities. In 1916, the New England Water-Works Association surveyed 304 cities and towns, largely in New England, and found that 95 (31 percent) of these cities used lead or lead-lined services (CSP, pp. 326-30; and EN, p. 594). A second and independent sample is more geographically diverse and includes 797 cities and towns observed in 1900 from all over the United States. Of these cities, 209 (26 percent) used lead or lead-lined services exclusively; 137 (17 percent) used lead or lead-lined services in conjunction with some other material type, such as galvanized iron or cement-lined iron; and 451 (57 percent) used no lead. Table 1, which breaks down lead use by city size, suggests a strong positive correlation between lead use and city size. For cities with populations less than 8,000, 33 percent used lead service pipes. In contrast, for cities with populations between 30,000 and 300,000, 72 percent used lead pipes; and for the largest cities, those with populations greater than 300,000, all but one (94 percent) used lead service pipes. ${ }^{11}$

\section{B. Lead in Massachusetts Tap Water}

In 1900, the Massachusetts State Board of Health launched an investigation into the amount of lead contained in household tap water in twenty-two municipalities across the state. Health officials took several samples of water from household faucets in these cities after the water had

services, but in a paved street the greater duration of life probably more than compensates for the extra cost, and in places where the streets are occupied by other pipes and conduits the ease of getting over and under these obstructions with a flexible pipe is a great advantage."

${ }^{11}$ The construction of this sample is described in Troesken and Beeson (forthcoming). 
passed through lead service pipes; measured the lead content of these samples; and reported their findings in the annual report of the board of health. Officials also reported data about the chemical composition and qualities of the local water supply, including how hard the water was, and the amount of free- $\mathrm{CO}_{2}$ (carbonic acid) it contained. (Hereafter, all reports of the Massachusetts State Board of Health are cited as MSBH).

The data derived from this investigation suggest four important observations. First, by today's standards, lead levels in these twenty-two towns were extraordinarily high. Second, the use of lead pipes increased the amount of lead contained in household tap water. Depending on the water source, lead service lines increased the amount of that otherwise would have been in the water by a factor from three to eight. Third, there were significant interaction effects. The amount of lead added to drinking water by lead service lines depended on at least two characteristics of the water supply: how hard it was, and how much free- $\mathrm{CO}_{2}$ (carbonic acid) it contained. In towns with soft water, or with water containing high levels of free- $\mathrm{CO}_{2}$, large amounts of lead dissolved into the water supply if lead pipes were employed; in towns with hard water, and water with little free- $\mathrm{CO}_{2}$, relatively small amounts of lead dissolved into the water. Fourth, the amount lead taken from the interior walls of lead service pipes varied inversely with the age of the pipe. Holding the corrosiveness of water supplies constant, less lead was dissolved from old pipes than from new.

Table 2 reports the lead levels in Massachusetts tap water, and indicates the extent to which these levels exceed current EPA guidelines. Health officials took two sets of samples, one for water following ordinary use, and another for water that was left standing in pipes overnight. There are two cities—Hyde Park and Lowell—for which there are two separate lead readings. These are given because in both Hyde Park and Lowell two separate water sources were used in each city, and the corrosiveness of the water varied across the sources. Notice that even in Cambridge and Cohasset, 
which had the lowest lead levels of the towns surveyed, the average amount of lead in household tap water that stood in pipes overnight exceeds current EPA guidelines by factors of 4 and 3, respectively. In the median (mean) city, the lead level in water that stood in pipes overnight exceeds current guidelines by a factor of 19 (58). And for three cities-Hyde Park (old well); Lowell (Cook well); and Middleborough—-the average lead levels in standing water exceed current guidelines by factors of 202, 169, and 411, respectively. The discussion thus far has focused on sample averages. If one considers the observed high in each sample, lead levels exceed current EPA guidelines by factors as large as 750 .

The inordinately high lead levels observed in Massachusetts drinking water in 1900 did not necessarily arise from the use of lead service pipes. There were plenty of other sources of lead in tap water, particularly industrial and natural pollution of water sources, and lead-based pipes and solders used for the interior plumbing of homes. Two experiments, however, suggest that lead dissolved from the interior lining of service pipes was the primary source of lead in drinking water. In the first experiment, eighteen samples of water from the Lowell, Boulevard well were passed through an iron service line. The lead levels for the iron service line can then be compared to the lead levels reported in table 2, which are for the same water but passed through a lead pipe. Passed through a non-lead pipe after ordinary use (standing overnight), the Lowell, Boulevard well water contained, on average, one-third (one-eighth) the amount of lead contained in water from the same source passed through a lead pipe (MSBH 1900, pp. 491-97). In an independent experiment conducted by two New York health officials during the 1930s, very similar findings were obtained. Employing the identical experimental design as was used for Lowell, these officials passed water from the identical source in the Catskills through lead and iron pipes. The average lead content for water that passed through the lead pipe was .1425 parts per liter of water; the average lead content for water passed 
through the iron pipe was .025 , one sixth the amount found in water from the lead pipe. ${ }^{12}$

Table 3 demonstrates how the chemical composition of water affected the amount of lead that was dissolved from the interior walls of lead service pipes. Using the observations reported in table 2, lead levels in each town are regressed against the characteristics of the town's water supply, specifically, the acidity and hardness of the water. ${ }^{13}$ Water that contained high levels of free- $\mathrm{CO}_{2}$ (carbonic acid) and was relatively soft was corrosive and introduced more lead into the water supply than water that had low levels of free- $\mathrm{CO}_{2}$ and was hard. The correlation between a water's chemical composition and its effects on lead service lines will be exploited later in the paper. In particular, given the findings reported in table 3, one expects that the adverse health effects of lead service lines would have been more severe in cities with corrosive water supplies than in those with less corrosive supplies. And this is exactly what the empirical work presented below shows.

The age of lead water lines also affected how much lead was dissolved into drinking water.

Overtime, oxidization formed a protective coating on the interior of lead water lines and this limited how much lead leached into the water. ${ }^{14}$ In short, because of oxidization, holding the corrosiveness of local water supplies constant, systems with old lead pipes exposed consumers to much less lead than systems with new lead pipes. Evidence of the influence of age and oxidation on the rate at which lead was absorbed into drinking water comes from experiments and historical observation. For example, Quam and Klein (1936), using water samples with consistent chemical properties,

${ }^{12}$ See Quam and Klein (1936), p. 779, particularly tables I and II.

${ }^{13}$ The hardness of a particular water source was positively correlated with its levels of dissolved calcium and magnesium.

${ }^{14}$ Unfortunately, the data sources used to create tables 2 and 3 do not include information about the age of the associated water lines. If they had, it would be possible to add age to the regressions reported in table 3 and interact age with the hardness and acidity variables. 
compare the amount lead that was taken off old lead pipes and new pipes. They find that substantially more lead was introduced into water stored in new pipes than in old pipes. By the same token, studies by the Massachusetts State Board of Health conducted during the 1890s and early 1900s found that the most serious cases of lead poisoning tended to occur with newer lead pipes as opposed to old pipes. ${ }^{15}$ The inverse correlation between age of pipe and lead levels will be exploited in the empirical work below. In particular, given the evidence just cited, one expects that, holding water quality constant, cities with new lead service pipes would have experienced more severe health effects than cities with relatively old lead services.

\section{Lead Poisoning: Etiology, Diagnosis, and Prevention}

To foreshadow later findings, the empirical work below suggests that the use of lead service pipes had an enormous effect on infant mortality rates and stillbirth rates, increasing such rates by 25 to 50 percent. For such findings to be believable, three questions need to be addressed. First, was the amount of lead contained in Massachusetts drinking water sufficiently large to kill a small child, or an unborn fetus in the case of stillbirth rates? The survey data presented in table 2 alone do not answer this question - to a sceptic, showing that lead levels in Massachusetts tap water exceeded current EPA guidelines by factors as large as 700 might say more about the unreasonableness current regulations than it does about the effects of such levels on historical health outcomes. Second, a 25 to 50 percent increase in death rates suggests that in at least some places, lead-poisoned water was killing one-fifth to one-third of all infants. How could such an enormous factor in infant mortality have gone undetected? Third, how difficult was it for private homeowners to prevent

\footnotetext{
${ }^{15}$ See, for example, Milton News, February 15, 1902, p. 1. The paper reported that the chairman of the State Board of Health, a Dr. Walcott, stated: "the use of lead pipe for conveying water ought to be discouraged generally, as there is always danger of poisoning from it. The newer the pipe, the greater the danger [emphasis added]." See also, MSBH (1895), pp. xxiv, and 30-31.
} 
water-related lead exposure? For example, today health officials recommend flushing pipes before using tap water for drinking or cooking to remove any residual lead from plumbing fixtures. Were such practices known in 1900 ? Would they have had significant effects?

\section{A. Was There Enough Lead in Massachusetts Tap Water to Kill an Infant?}

Regarding the first question, a reasonable starting point is to look at the effect lead water mains had an adult health. Troesken and Beeson (forthcoming) use a sample of more than two thousand Union-Army veterans to explore the impact of lead water lines on adult health. Comparing the health outcomes of veterans living in towns with lead water lines to those of veterans living in towns with non-lead mains, Troesken and Beeson find evidence that veterans in leaded towns had elevated rates of dizziness, hearing problems, and perhaps kidney failure. This study understates the impact of lead water pipes on adult health outcomes because it uses an imprecise indicator of water-related lead exposure. The study, for example, did not control for years-ofexposure to lead pipes, or the corrosiveness of the local water supplies. Nonetheless, the fact that this study finds evidence that the use of lead water lines increased the rate of nephropathy (kidney failure) among adult males is suggestive. Nephropathy is observed in adults when blood levels reach between 40 and 100 micrograms per deciliter (: g Pb/dl). Similar blood lead levels in children cause encephalopathy (brain-swelling). ${ }^{16}$

Along the same lines, in its thirtieth annual report, the Massachusetts State Board of Health described the types of symptoms that were "liable to ensue after the continuous use of water containing small quantities of lead." The board of health suggested that the symptoms progressed slowly. They began with "anemia," "depression," and "often constipation and indigestion." Other early symptoms might have included "a loss of appetite" and "an unquenchable thirst." With

\footnotetext{
${ }^{16}$ See Perazella (1996) and Xintaras (1992).
} 
continued exposure, "colic" and "abdominal hardness and pain" were common symptoms. The board of health stated that, in more severe cases, peripheral neuropathy (paralysis in the extremities) was a common feature of water-related lead poisoning (MSBH 1899, p. xxxiii):

Far more commonly, lead paralysis is manifested. It may occur after a single attack of chronic lead poisoning, but is more often the result of a series of attacks, and occasionally occurs without being preceded by any attack. The upper extremities, and especially the extensor muscles, are most commonly attacked, those of the hand and forearm first suffering.

In an adult, this feature-paralysis in the arms and hands-is consistent with blood lead levels between 40 and $100: \mathrm{g} \mathrm{Pb} / \mathrm{dl}$. As stated above, similar blood lead levels in children cause encephalopathy.

Further evidence of the adverse health effects of lead water lines can be found in two welldocumented episodes of water-related lead poisoning. These two episodes are presented in detail below and involve Milton, Massachusetts--a small town outside of Boston—and Lowell—a large industrial town in northeastern Massachusetts. These case studies demonstrate that, in a fairly short time, lead service lines could introduce enough lead into drinking water to cause death and insanity among adults. Given the severity of symptoms observed in adults, one can reasonably assume that similar levels of exposure for infants would have had even more severe consequences. Holding exposure constant, children experienced more severe symptoms than adults. Lead exposure is especially serious because children absorb more lead than adults, and because the developing nervous systems of children are more susceptible to the effects of lead than are the systems of adults (Needleman and Belinger 1991; and Nebraska Epidemiology Report, 2001).

Finally, it is useful to review the epidemiological evidence on the effects of lead exposure on fetal and infant health. Studies conducted during the early twentieth century suggest that high levels of maternal lead exposure can have enormous effects on the health outcomes of the very young. In 
one British study, women working in the lead industry experienced miscarriages and stillbirths at rates 3 times greater than those of women working in non-lead industries. A French study found that out of one thousand pregnancies among women working with lead, 608 culminated in premature delivery. According to a study published in 1908, "in certain Hungarian villages, where pottery glazing has been a home industry for generations, children born of lead poisoned parents are not only subject to convulsions, but, if they live, often have abnormally large, square heads, and this condition is associated with a lowered mentality." 17

The strongest modern-day evidence that lead exposure, even in very small amounts, can result in fetal and infant death is presented by Wolpaw Reyes (2003). Using state-level data from the U.S., Wolpaw Reyes shows that the phase-out of leaded gasoline reduced infant mortality rates by 3 to 4 percent. Competing studies of the effects of lead on infant health are plagued by concerns about small samples, unobserved heterogeneity, and reverse causality whereby pre-existing poor health might determine the amount of lead exposure. ${ }^{18}$ Wolpaw Reyes, however, is able to control for most relevant confounding variables and uses variation in the consumption of leaded gasoline - a truly exogenous variable - to isolate the effects of moderate levels of lead exposure.

\section{B. How Did All This Lead Poisoning Go Undetected?}

Regarding the second question—how did all of this lead poisoning go unnoticed? — it is useful to consider the diagnostic challenge lead poisoning represented. Consider first diagnosing lead poisoning in adult victims. Three adults with similar blood lead levels might have presented

${ }^{17}$ These and other studies are summarized in a report by United States Bureau of Labor Statistics (1919).

${ }^{18}$ See Pocock et al. 1994 for a comprehensive review of the relevant epidemiological studies and their methods. Pocock's review focuses on the effects of intelligence, however, and does not discuss the effects of lead on infant mortality. For a more limited, but also a more up-to-date review of the effects of lead on infant and fetal health outcomes, see Wolpaw Reyes (2003). 
entirely different symptoms to the turn-of-the-century physician. One victim might have suffered from kidney failure, a second from a wrist palsy and constipation, and a third from increased blood pressure, dizziness, and anemia. Accurate diagnoses were further undermined by interaction effects with other environmental and behavioral characteristics. For example, if a lead-poisoned patient drank alcohol to excess, liver failure was common; undue amounts of lead and alcohol virtually guaranteed the victim would develop cirrhosis of the liver. In any of these examples, a physician might have attributed death to causes other than lead, even though the underlying pathology was caused by lead poisoning as opposed to, say, alcohol or a genetic predisposition to kidney disease. ${ }^{19}$ For children, diagnosing lead poisoning accurately was even more problematic. In a recent social history of lead poisoning in America, Warren (2000, pp. 34-35) describes cases of childhood lead poisoning during the early twentieth century that were misdiagnosed as feeble-mindedness, summertime colic, appendicitis, polio, and convulsions and paralysis of unknown origin. Warren, however, argues that the most common misdiagnosis for lead poisoning was tubercular meningitis (p. 35):

The early stages of both diseases produce appetite loss, headache, vomiting, and acute constipation. Gradually, neurological symptoms arise: photophobia, rigidity of the neck, lethargy, and paralysis of the limbs or facial nerves. The most serious cases end in convulsions, coma, and death.

In summarizing a study of 105 tubercular meningitis cases treated in the Boston Children's Hospital between 1910 and 1913, Warren (2000, p. 35) strongly suggests that more than half of these cases were, in fact, the result of lead poisoning and not tubercular meningitis. This study found that tubercle bacilli were identified in less than 25 percent of the cases, and that in over 60 percent of the

\footnotetext{
${ }^{19}$ On the difficulties of diagnosing lead poisoning on historical actors, see Depisch et al.
} (1999) and Ravin and Ravin (1999). These studies explore the possibility that President Jackson and the painter Goya suffered from lead poisoning. On lead affecting multiple body systems, see Troesken and Beeson (forthcoming) and Xintaras (1992). 
cases, there was no pathological evidence of tubercular meningitis.

Even with the aid of late-twenty-first century technology and medical training, childhood lead poisoning remains a difficult and elusive diagnosis. Consider the recent case of a two-year-old girl in New Hampshire reported by the Centers for Disease Control and Prevention (2001). The child was admitted to the emergency room of a community hospital with vomiting and a low-grade fever. A throat swab for a streptococcal infection was positive, and the girl was discharged with a prescription for an appropriate antibiotic. The girl's vomiting continued, however, and she was readmitted to the same hospital two weeks later. The next day she was transferred to a tertiary-care hospital. Within a few hours of her transfer, she became unresponsive, and had difficulty breathing. Doctors placed her on a respirator and performed a brain scan. The brain scan revealed diffuse cerebral swelling and dilated ventricles. A blood test later showed that the girl had blood lead levels of $391: \mathrm{g} \mathrm{Pb} / \mathrm{dl}$ — any blood lead level above 100 is potentially fatal. Chelation therapy, the standard treatment for lead poisoning, was administered, but it was too late. The girl became comatose and died two days later.

Because lead affected multiple body systems, and because the symptoms of lead poisoning varied greatly from person-to-person according to the individual's size and general ability to withstand lead exposure, it was difficult for doctors in the nineteenth and early-twentieth century to diagnose lead poisoning on an individual basis. Absent some external or circumstantial condition to suggest lead poisoning-e.g., the patient worked as a painter, or lived close to a lead refinery-doctors appear to have been reluctant to ascribe the periodic case of paralysis, colic, constipation, kidney or liver trouble, and the like, to anything other than arthritis, diet, family history of disease, or excessive drinking. In this regard, it useful to consider two well-documented episodes of water-related lead poisoning in Massachusetts. These cases involved a situation where a sudden 
change in water acidity, or the introduction of new lead service lines, generated an epidemic-like outbreak of lead poisoning in a particular city that was concentrated over a short time period. Situations like this made it possible for local physicians to identify a constellation of lead-related symptoms across a fairly large population.

Consider, then, the experiences of Milton and Lowell (MA). ${ }^{20}$ In 1900 and 1901, workers associated with the Boston public works department were installing public sewer lines in Milton. Ultimately, these lines were to be connected to Boston's larger sewer system. In the course of installing the sewer lines, workers had to drain several private water wells, and left a handful of families without water. As compensation for this, Boston's sewer commission decided to connect these households to the public water system without charge. New lead service pipes were used to connect the households to water mains. During the ensuing eighteen months, cases of lead poisoning developed in eight of the families connected with new lead pipes; among the eight families, there were seventeen or eighteen documented cases of lead poisoning. Some of the cases were quite severe: there was one death, one young mother went insane, and in several other cases, individuals had been exposed to sufficiently high levels of lead to develop the only tell-tale sign of serious lead poisoning: a blue gum line. Tests of the drinking water of these eight households revealed lead levels well above the maximum level then recommended by health officials in Massachusetts (.5 parts per million). A subsequent court case found that the lead water lines were the cause of the lead poisoning. In this case, a husband sued claiming that water-related lead

${ }^{20}$ In its annual reports, the Massachusetts State Board of Health documented cases of waterrelated lead poisoning in the following five towns: Milton; Lowell; Fairhaven; Kingston; and Milford. The experiences of Milton and Lowell were well-documented by state authorities; the three other cases were given little, if any, explanation from state officials. Accordingly, the discussion here focuses on Milton and Lowell. See, generally, MSBH (1890-1900). 
poisoning resulted in the loss of his wife's society and affection. ${ }^{21}$

Significantly, public health officials believed that there were many more cases of lead poisoning in Milton, but that these went unreported because physicians and victims incorrectly attributed the symptoms of lead poisoning to other causes. Nor did health officials believe that cases of lead poisoning were limited to homes connected with the new lead lines. Lead service pipes were used throughout the town and about 90 percent of all households with public water used lead pipes to connect to street mains. When the State Board of Health measured lead levels in drinking water in areas with old service pipes they found dangerously high lead levels there as well, though the levels were lower than in areas with new services. It appears that what enabled Milton doctors to identify lead poisoning among the eight families with new pipes is that they were confronted by a large mass of patients in a very short period of time, all with a constellation of puzzling symptoms. Unfortunately for patients living in areas with older pipes, there was no sudden, epidemic-like outbreak of symptoms related to lead poisoning. There was, instead, a gradual accumulation of various individual-specific symptoms, appearing randomly across patients and time.

In Lowell, Massachusetts, there were concerns about the health effects of using lead service pipes from the time the city's water system was first installed. A group of physicians in Lowell issued a report in 1842 that emphasized the corrosiveness of the city's water supply and its tendency to dissolve large and unhealthy quantities of lead from the interior walls of lead pipes. The data in table 2, which show the amount lead contained in Lowell's drinking water, support the conclusions of this report. Despite the physicians' report and its strongly worded recommendation that Lowell not use lead service lines, city officials installed lead pipes because the "water department and local

\footnotetext{
${ }^{21}$ This paragraph is based on articles in the following issues of the Milton News: January 11, 1902, p. 1; February 1, 1902, p. 1; and February 15, 1902, pp. 1 and 4. See also, Welsh v. Milton Water Company, 200 Mass. 409 (1909).
} 
plumbers believed that was the only proper pipe to use." The source of this preference was lead's "economy and ease of handling." During the 1890s, Lowell tapped new water sources that were even more acidic and corrosive than the original sources described by the physicians' committee in 1842. The result of this shift to a more corrosive water supply was a sudden, epidemic-like outbreak of lead poisonings with serious health consequences for some people. Health authorities in Lowell documented at least fifty cases of water-related lead poisoning among adults. In typical cases, people experienced colic, constipation), severe headaches, and paralysis in the hands. In more severe cases, individuals lost the ability to walk, developed a blue gum line, and became emaciated. One elderly woman died from a cerebral hemorrhage shortly after being diagnosed with severe lead poisoning — as noted above, high levels of lead exposure can cause cerebral swelling and softening of the brain's vascular system. Water from her tap contained .29 grains of lead per gallon. ${ }^{22}$

In terms of promoting a more accurate understanding of the effects of lead water lines, it is perhaps unfortunate that there were not more of these epidemic-like outbreaks of lead poisoning. If there had been, the dangers of lead pipes would have been clear and compelling. And municipalities might have been forced to abandon lead pipes for pipes that were slightly less desirable from an engineering standpoint, but much safer from a public health standpoint. Instead, as the data below make clear, lead water pipes quietly killed thousands of children every year.

\footnotetext{
${ }^{22}$ These quotations in this paragraph are from R.J. Thomas, an engineer at the Lowell water company, made at a conference of the New England Waterworks Association. See CSP, pp. 355-57. Other information in this paragraph comes from MSBH (1898), pp. xxxii-xxxiii. A detailed account of the outbreak of lead poisoning in Lowell can be found in the Thirty-First Annual Report of the Massachusetts State Board of Health. See MSBH (1900), pp. xxxiv-xxxix.
} 


\section{Private Prevention of Lead Poisoning}

For the results presented below to be credible, a third question must be addressed as well: how difficult was it for homeowners in 1900 to monitor and control the amount of water-ingested lead their families were exposed to? If the answer is that it what was fairly easy, it is difficult to sustain the claim, no matter how clear the data, that water-related lead exposure was increasing infant mortality rates by 25 to 50 percent in the typical Massachusetts town. In 1900, there were public officials who recommended that families with lead service pipes flush their plumbing systems by running taps for two minutes before using water for drinking and cooking. And flushing pipes in this way did eliminate some of the excess lead in tap water, but it did not eliminate all of it. As the data in table 2 show, there was still plenty of lead contained in water from taps following ordinary use. $^{23}$

Nor is it clear that all that many consumers were aware of such strategies, or even of the dangers of water-related lead poisoning. In turn-of-the-century America, most people were far more concerned about organic pollutants in tap water than they were about inorganic pollutants such as lead. Some historical observers even believed that a modicum inorganic pollution in water was a good thing because it killed the pathogens that caused typhoid and other diarrheal diseases (Melosi 2000, pp. 241-46). Furthermore, it was costly for homeowners to monitor the amount of lead in drinking water. The only way to have been sure of the lead content of one's tap water was to have it tested (EN, p. 595). Finally, as late 1936, the American Journal of Public Health was publishing articles exhorting homeowners to flush their pipes before drinking tap water in order to minimize water-

${ }^{23}$ Consider this excerpt from the Milton News (February 15, 1902, p. 4), quoting the Massachusetts State Board of Health: "If the water is allowed to run freely, the quantity of lead taken up will be less than when the water is allowed to stand in the pipe for considerable time; but even when allowed to run freely it may contain a sufficiently large quantity of lead to produce serious injury." 
related lead exposure. ${ }^{24}$ This suggests that at least some portion of the population was unaware of this strategy.

\section{Age and Vulnerability to Environmental Insults: A Model}

The simplest and most direct way to measure impact of lead water lines on infant mortality would be to get reliable statistics on the number of infants killed by lead poisoning across all Massachusetts towns. Unfortunately, no such data exist. As explained earlier, it was difficult enough to diagnose lead poisoning among adults who were able to describe their symptoms with at least some accuracy; diagnosing such a condition among infants was nearly impossible. Even a disease like typhoid, which had a relatively well-defined etiology and symptomology, was never diagnosed in young children because of their inability to accurately describe their symptoms. ${ }^{25}$ Without a direct measure of lead-related deaths among very young children, such deaths will be estimated indirectly using data on age- and cause-specific death rates. These estimates are based, in part, on an explicit model of the relationship between age and vulnerability to fatal environmental insults, particularly lead poisoning and exposure to infectious diseases. Accordingly, the model developed here provides a clear set of testable implications that will guide the empirical work later in the paper.

In this model, children can die from one of two types of environmental insults: organic and inorganic. Organic insults follow exposure to any number of viral or bacterial agents; inorganic insults follow exposure to inanimate and toxic agents such as lead. It is assumed that there is only

\footnotetext{
${ }^{24}$ See, for example, Quam and Klein (1936, p. 780) who write: "the observations reported here make it appear quite obvious that domestic service pipe lines made entirely or even in part, of lead should be thoroughly flushed after a period of rest before the water is used for drinking or for cooking foods."

${ }^{25} \mathrm{On}$ the difficulty of diagnosing typhoid in children, and the tendency of nineteenth century doctors to confuse typhoid with malaria, see Troesken (forthcoming), particularly chapters 3 and 7.
} 
one type of inorganic insult—water-related lead exposure-but that there are a potentially infinite number of organic insults, ranging from typhoid and tuberculosis to diphtheria and measles, and all of the various diseases and strains of diseases in between. It is also assumed that exposure to lead remains constant overtime, but that exposure to specific diseases varies greatly from year to year. Epidemics drive the year-to-year variation in specific diseases. In one year, there is an epidemic of typhoid; in the next, an epidemic of measles; in the next, an epidemic of diphtheria; and so on. This situation mirrors the United States in 1900, where specific infectious diseases could vary sharply from year to year, and where infectious diseases, taken collectively, were a leading cause of death, particularly among children.

Consider then the pattern in lead-related deaths suggested by figure 1. This figure follows a birth cohort over a four year time span, from birth (year 0) up to age four (year 4). The amount of lead in this birth cohort's environment is constant over time, and is given by $l^{*}$. In the first year of life, the ability to survive lead exposure is uniformly distributed over the line XYZ. The proportion of the population above $Y$ are able to withstand lead levels as high as $l^{*}$ and survive, but those below $Y$ are not so robust and die. In subsequent years, only those most able to eliminate lead from their systems are left in the population, and their lead-eliminating abilities improve over time as their bodies develop. A plausible age-vulnerability profile for lead-related deaths is given in figure 2, which shows a positive death rate for lead poisoning for persons aged zero to one, but a zero death rate for older children. The exact structure of this profile is an empirical question; death rates might drop to zero at six months or two years. The central point is that at some age there will be a sharp discontinuity and lead-related deaths will drop to zero.

Consider next, the construction of an age-vulnerability profile for organic insults related to exposure to infectious diseases. There are $n$ infectious diseases, given by, $x_{1}, x_{2}, x_{3}, \ldots, x_{n}$. For 
each disease $x_{\mathrm{k}}$, the death rate from the disease in non-epidemic years is zero; for epidemic years, the death rate from $x_{\mathrm{k}}$ equals $x^{*}$, where $x^{*}>0$. It is also assumed that if there is an epidemic of $x_{\mathrm{k}}$ in year $t$, there will not be another epidemic of $x_{\mathrm{k}}$ until the year $t+n$. In this context, there is no reason to believe that if a child survives an epidemic of $x_{\mathrm{k}}$ in period $t$, he or she will necessarily survive an epidemic of $x_{(\mathrm{k}+1)}$ in period $t+1$. Put simply, exposure to typhoid in the first year of life confers on the child no immunity to the measles he or she will be exposed to in the second year of life. On the contrary, fighting off one infectious disease in the first year of life might leave the child so weakened and compromised he or she will have a much harder time fighting off new infections in subsequent years (Costa 2000; Fogel and Costa 1997).

Figure 3 illustrates, following the evolution of three infectious diseases over a three year period. In year one, there is an epidemic of disease $x_{1}$, while diseases $x_{2}$ and $x_{3}$ are dormant; in year two, there is an epidemic of disease $x_{2}$, while diseases $x_{1}$ and $x_{3}$ are dormant; and so on. For each disease $x_{\mathrm{k}}$ considered individually, one imagines a scenario that is similar to that of lead: the youngest children are the most vulnerable to the disease because of their small size and relatively underdeveloped immune systems. However, in contrast to lead-related deaths, exposure to a disease in the previous period has not eliminated all of the vulnerable children in older populations, and has left some of those who survived disease $x_{k}$ in year $\mathrm{k}$, weakened and especially vulnerable to disease $x_{(k+1)}$ in year $k+1$. Consequently, whenever the epidemic of disease $x_{k}$ hits, infants will not be the only ones who die; so too will older children. Given their relative size and better developed immune systems, older children will probably die at a lower rate than younger children, but some will perish nonetheless. A plausible age-vulnerability profile for disease-related deaths is given in figure 4. As in figure 2, the exact structure of this profile is an empirical matter. But the basic point is that, in contrast to the age-profile for lead-related deaths—-which suddenly drops to zero once a child 
reaches some threshold in development—disease-related deaths decline slowly as one moves up age categories.

Until now, it is has been implicitly assumed that the ability to withstand lead exposure is not correlated with the ability to withstand exposure to infectious diseases. This, of course, need not have been the case historically, and two possibilities suggest themselves. One possibility is that vulnerability to fatal lead poisoning is positively correlated with vulnerability to any infectious disease $\chi_{\mathrm{k}}$. In this case, at least some of the infants killed by water-related lead poisoning would have died anyway once exposed to disease $x_{\mathrm{k}}$. Another possibility is that exposure to lead, even if it is not fatal, undermines the health and development of children, leaving them more vulnerable than they otherwise would have been to infectious diseases. In this case, a non-lethal dose of lead in an early-life stage raises the probability of dying from an infectious disease in a later-life stage. ${ }^{26}$

In sum, the model suggests three testable propositions. First, lead poisoning would affect only the very young; once the weakest and least robust children, in terms of their ability to withstand lead exposure, are eliminated from the population, water-related lead exposure would have no systematic on effect human mortality. Second, although infectious diseases also affect the smallest and most vulnerable children disproportionately, infectious diseases, in contrast to lead poisoning, do have a systematic effect on the mortality of older and more robust children. Third, the use of lead water lines might be correlated with death rates from infectious diseases, but a priori, it is not clear if this correlation would be positive or negative.

\footnotetext{
${ }^{26}$ There exists some evidence that lead poisoning might impair the human immune system. See Cohen et al. (1989); Fischbein et al. (1993); and Sata et al. (1998).
} 


\section{Estimation: Issues and Strategies}

To identify the effects of lead water mains on fetal and infant death rates, variants on the following generic equation are estimated using cross-sectional data from the year 1900:

$$
y_{\mathrm{i}}={ }_{0}+\mathrm{N} l_{\mathrm{i}}+x_{\mathrm{i}} \$+e_{\mathrm{i}}
$$

where, $y_{\mathrm{i}}$ is the infant mortality rate, or the stillbirth rate, for city $\mathrm{i}$; $l_{\mathrm{i}}$ is a dummy variable that assumes a value of one if city i employed lead service lines, and zero if the city employed iron, cement-lined, or some other non-leaded metal; $\boldsymbol{x}_{\mathbf{i}}$ is a vector of control variables that measure such things as population, infectious disease environment, and the development of infrastructure related to public health; and $e_{\mathrm{i}}$ is a random error term.

There are two concerns with the regression specified in equation (1). First, death rates might have been measured with greater accuracy in large towns than in small ones. To address this concern, all of the observations are weighted by population. ${ }^{27}$ Second, it is possible that the use of lead water mains is correlated with some unidentified factor that also influences the health outcomes of young children. In which case, the estimated coefficient on the dummy for lead water lines will be biased. A priori, it is not clear whether the estimated effects of lead would be biased upward or downward. One might imagine a world where only cities who were relatively careless about health used lead service lines, in which case the coefficient on the lead-use dummy would be biased upward. Alternatively, one might imagine a world where cities that already had serious public health problems avoided using lead service lines, for fear of exacerbating their problems any further. In

${ }^{27}$ In particular, all regressions are estimated using STATA (7.0) and the data are weighted according to the aweights algorithm. This weighting scheme uses weights that are inversely proportional to the variance of an observation so that the variance of the $j$ th observation is assumed to be $\mathrm{F}^{2} / \mathrm{w}_{\mathrm{j}}$, where $\mathrm{w}_{\mathrm{j}}$ is the weight of the $\mathrm{jth}$ observation. 
this case, only towns with relatively low death rates would have been willing to risk the dangers associated with using lead service pipes, and the coefficient on the lead dummy would be biased downward.

For the moment, let the focus be on factors that might impart an upward bias on to the estimated effects of lead water lines. In this regard, consider a world where the use of lead water mains was correlated with something one might call the "health consciousness" of a community. Simply put, communities that were very health conscious, and were attune to the dangers of using lead pipes, installed iron or cement-lined pipes, while communities that were not so health conscious, and did not know about, or were indifferent to, the dangers of lead pipes, went ahead and installed lead service lines. Whatever its effect on the probability of using lead water lines, health consciousness also would have had an independent and significant effect on infant mortality rates. The result? Infant mortality rates would have been lower in the cities using non-lead pipes than in those using lead pipes, even if both sets of cities had chosen to use the same type of pipes. Letting $h_{\mathrm{i}}$ indicate the level of health consciousness in town $\mathrm{i}$, this situation can be formalized by re-writing equation (1) as:

$$
y_{\mathrm{i}}={ }^{\prime}{ }_{0}+\mathrm{N}^{\mathrm{T}} l_{\mathrm{i}}+*_{h_{\mathrm{i}}}+x_{\mathrm{i}} \$+e_{\mathrm{i}} \text {. }
$$

If one accepts the plausible assumption that $h_{\mathrm{i}}$ is negatively correlated with both $y_{\mathrm{i}}$ and $l_{\mathrm{i}}$, it is clear that when $h_{\mathrm{i}}$ is omitted from the regression, as equation in (1), the estimated coefficient on lead pipes will reflect the effects of both $h_{\mathrm{i}}$ and $l_{\mathrm{i}}$, and will be biased upward so that $\mathrm{N}>\mathrm{N}^{\mathrm{T}}$.

To address the concern about omitted variable bias, five strategies are pursued. The first strategy explores the health effects of lead water pipes using age-specific death rates. This strategy grows out of the idea that very small children would have been more vulnerable to the effects of 
lead than older, more developed individuals. Given that smaller children experienced more severe health effects from lead than older children, holding everything else constant, one expects that the use of lead water pipes would have had much larger effects on, say, stillbirth rates and infant death rates (children aged 0-1) than on death rates of older children, say those aged 4-10. If the use of lead lines had been correlated with health-consciousness, one would not necessarily expect to observe this pattern.

The second strategy explores the correlation between the use of lead service pipes and infectious disease rates. If it were a lack health consciousness, and not lead water pipes per se, that drove up infant death rates in towns with lead water lines, one would expect to observe a positive correlation between the use of lead water lines, and infectious diseases such as scarlet fever, measles, and the like. As explained in section IV, a positive relationship between lead use and infectious disease might also reflect the fact that exposure to unhealthy lead levels at a young age left children weak and compromised in terms of their ability to fight off infectious diseases. Hence, a positive relationship between lead use and infectious disease rates does not, by itself, prove that it was a lack of health consciousness, and not the use of lead water pipes, that caused the elevated rates of infant death in towns with lead lines. However, a negative coefficient, or a very small positive one, on the lead dummy would certainly undermine the case that it was health consciousness, or a lack thereof, that drove up infant mortality rates in towns with lead pipes.

The third strategy is to control for health consciousness through direct and remedial steps. For example, health consciousness probably would have manifested itself in other public investments. Presumably, health-conscious voters would have demanded the construction of sanitary sewers and encouraged local officials to use ground water for the public water supply_ ground water was much more likely to have been germfree than above-ground sources. It 
is a simple matter to include controls for such investments. By the same token, holding everything else constant, health consciousness would have also manifested itself in lower infectious disease rates. As previous discussion suggests, health-conscious families and towns probably would have been more aggressive than those who were indifferent to health outcomes in undertaking the public and private precautions necessary to prevent the spread of infectious diseases. Again it is a simple matter to include controls for such factors by adding variables that control for the infectious disease rates observed in cities.

The fourth strategy is to employ instrumental variables. The goal here is to identify an instrument that is correlated with lead use, but not health outcomes. Reasonable instruments are available and these are related to the financing of service pipes, the complexity of urban infrastructure, the number of large-industrial users of water, and the ownership history of the local water system (e.g., had the local water company always been publically-owned, or had it once been private?). As will be made clear below, each of these variables has a solid theoretical and historical justification for use as an instrument.

The fifth strategy uses interaction effects to recreate the same natural variations that caused outbreaks of lead poisoning in Lowell and Milton. Recall that in Lowell, a change in the water supply increased the acidity and corrosiveness of water distributed through lead pipes, which in turn increased the amount of lead in drinking water. The "Lowell experiment" is recreated by interacting the lead dummy in equation (1) with a measure of the acidity of local water supplies. This procedure shows that infant mortality rates (and stillbirth rates) were positively correlated with acidity in towns with lead water lines, but were uncorrelated in towns with non-lead water lines. It is difficult to argue that acidity of water supplies was positively correlated with health consciousness in cities with lead lines, but somehow uncorrelated in cities non-lead lines. And in this way, interacting acidity 
measures with the lead dummy approximates a true natural experiment.

As for the Milton, recall that the introduction of several new lead service pipes, which were subject to more internal corrosion than old lead pipes, increased the amount of lead in Milton's drinking water. The "Milton experiment" is recreated by interacting the lead dummy in equation (1) with a measure of the proportion of water mains that were recently installed. This procedure shows that infant mortality rates (and stillbirth rates) were positively correlated with the proportion of water mains newly installed in towns with lead service pipes, and were uncorrelated with proportion of water mains newly installed in towns with non-lead service pipes. It is difficult to argue that proportion of water mains newly installed was correlated with health consciousness in cities with lead water mains, but uncorrelated with health consciousness in cities with non-lead mains.

\section{Results}

\section{A. Data Sources, Sample Composition, and Descriptive Statistics}

The empirical strategies just described are estimated using data originally compiled by the Massachusetts State Board of Health. Massachusetts collected and reported data on age-specific death rates and stillbirth rates for every town in the state with populations greater than 5,000 persons. The Massachusetts mortality data are well-known and have been widely used by historical demographers, largely because of their reliability, accuracy, and unusual detail. ${ }^{28}$ The data used here come from the Annual Report of the Massachusetts State Board of Health, 1900 volume (MSBH 1900). In addition to the data on health outcomes, data about water systems and the use of lead water lines across municipalities are also needed. These data come from The Manual of American Waterworks (Baker 1897) a volume compiled and edited by Moses N. Baker, a prominent public-health expert

\footnotetext{
${ }^{28}$ See Meeker (1972) and (1976), and Preston and Haines (1991, p. 50) for discussions of
} about the quality of the Massachusetts data. 
and the editor of the Engineering News, the leading trade journal for the municipal water industry. In one set of regressions (those dealing with the age of local water mains), the data from Baker (1897) are supplemented with data from 1890 volume of the Social Statistics of Cities originally compiled by the United States Census. ${ }^{29}$

Based on these sources, a sample of seventy-four Massachusetts towns is constructed. For most towns in the sample, there is information about the following (municipal-level) characteristics in the year 1900: age-specific death rates; cause specific death rates; population; whether the town used lead water pipes, or some other material such as iron; hardness of the local water supply; source of local water supply (i.e., above ground or below ground); and proportion of water mains installed during the previous ten years. For a small subset of the full sample (about twenty towns) there is also exact data on the amount of lead contained in household tap water from each town.

As for sample composition, summary statistics for the full sample, and for two subsamples are provided in table 4. As noted earlier, in all of the regressions, observations will be weighted by population to control for the possibility that death rates were measured with greater accuracy in large towns than in small ones. Accordingly, summary statistics are provided for the weighted and unweighted samples. In the unweighted full sample, the median town had a population of 11,319; the smallest town, a population of 4587; and the largest town, a population of 118,421 . Although the sample does not include Boston, by far the largest city in Massachusetts, the distribution is still skewed, with a mean population $(21,713)$ that is almost double the median. ${ }^{30}$ Thirty-percent of the

\footnotetext{
${ }^{29}$ Data from the Social Statistics of Cities are available online at the website of the Center for Population Economics at the University of Chicago. Data from this online version are employed here. population.

${ }^{30}$ Boston was dropped from the sample early on because it was such an outlier in terms of
} 
towns in the sample used lead water lines exclusively or in tandem with some other type of material; the remaining 70 percent used no lead pipes whatsoever. Infant morality rates in this sample of towns was high (349 deaths per 100,000 persons), but not unusually high for the urban Northeast (Preston and Haines 1990, pp. 53-59). The death rate from typhoid fever, an indicator of the overall quality of municipal sanitation, averaged 20 deaths per 100,000 persons in this sample; for the nation as a whole, the death rate from typhoid was 36 deaths per 100,000 persons (Troesken forthcoming, ch. 3). The index of water hardness varies from about 1 to 6 , with a mean value of 1.85 . Higher numbers indicate harder water. In the typical town, about 20 percent of all water mains had been installed in the previous ten years.

As for the subsamples, towns that used lead water pipes were, on average, almost 50 percent larger than towns that used non-lead pipes. Although infant mortality rates, stillbirth rates, and adult mortality rates are all higher in towns with lead pipes, typhoid rates are slightly lower in towns with lead pipes. Towns with lead pipes tended to have softer water than towns with non-lead pipes; the index of water hardness is nearly 25 percent larger in towns without lead. Lead and non-lead towns were qualitatively similar in terms of the proportion of their water mains that had been installed in the previous ten years. It is notable that the adverse effects lead water lines appear larger in the weighted sample than in the non-weighted sample. This is a potential concern as it might suggest that the use of lead is correlated with some unobservable variable related to both city size and health outcomes. Although concerns about unobserved heterogeneity will be formally addressed through instrumental variables and other techniques later in the paper, remedial statistical work suggests that lead water lines are not picking up some health effect related to city size. ${ }^{31}$

\footnotetext{
${ }^{31}$ If lead use were, in fact, correlated with some unobservable variable related to both city size and health outcomes adding controls for city size would reduce, by a large magnitude, the correlation between lead use and infant mortality. However, when the infant death rate (the death
} 


\section{B. Age and Vulnerability to Fatal Lead Poisoning}

Consider first econometric results exploring the relationship between age and susceptibility to fatal lead poisoning. The results are reported in table 5. Aside from measures of lead exposure, the regressions in table 5 include controls for city size (log of population), and overall quality of public infrastructure (as proxied by typhoid rates). Regressions (1)-(6) use a direct measure of lead exposure: the log of the lead content in tap water from a sample of twenty-one Massachusetts towns. For these twenty-one towns, the lead content of tap water has a large and statistically significant effect on the death rates of infants and children aged one to two. For infants, an increase in lead levels by one-standard deviation would have generated an 18 percent increase in mortality rates. For children aged one to two, a one-standard-deviation increase in lead would have generated a 12 percent increase in mortality rates. Lead levels have no systematic effect on the mortality rates of children aged two to four, or on children aged four to ten. Surprisingly, lead levels do have statistically significant effect on the mortality rates of all persons older than ten, but this effect is relatively small; a one-standard-deviation increase in lead levels only increased adult mortality by 3 percent. It is possible that older persons in this sample never went through the selection process described in section IV, because they grew up in an era when public water systems were relatively small and where water-related lead exposure was limited. ${ }^{32}$

rate for children from birth to age one) is regressed against a lead-use dummy, with no other control variables included in the regression, the coefficient on the lead dummy is 160.6 with a standard error of 36.2, and a t-statistic of 4.43. And when a battery of controls for population is added to the regression, the coefficient on the lead dummy falls somewhat, to 140.6, with a standard error of 33.7, and a t-statistic of 4.17. The controls for population include the following: the population level; the natural log of population; a dummy variable equal to one if population was between 10,000 and 30,000; a dummy variable equal to one if population was between 30,000 and 60,000; and a dummy variable equal to one if population was over 60,000 .

${ }^{32}$ Most cities did not begin building extensive water distribution systems until 1880; prior to this, most public water systems provided water to large industrial users and a handful of wealthy 
Regressions (7)-(12) identify the average effect of lead water lines on the mortality rates of young children. Notice that the sample size has more than doubled, because there are data on the use lead water lines for many more cities than there are data on the exact level of lead in tap water. The results here conform perfectly to the model developed in section IV. The use of lead water lines had a large and statistically significant effect on the mortality rates of the very young, but no effect, either statistically of substantively, on the mortality rates of older children and adults. In particular, the use of lead water pipes increased stillbirth rates by 59 percent above the mean level observed in town's with non-lead pipes; infant mortality rates by 39 percent; and the mortality rates of children aged one to two by 24 percent. That lead water lines had no discernible or systematic effect on the mortality rates of older children is consistent with the idea that only the smallest and most vulnerable children were vulnerable to fatal lead poisoning related to water. If the use of lead water lines per se was not undermining the health of young children, but was instead correlated with some unobserved variable called health consciousness, one wonders why the large and strong correlation between lead pipes and childhood mortality ceases to exist after children reach two years of age.

\section{Lead Water Pipes and Infectious Disease Rates}

In this section, the correlation between water-related lead exposure and infectious disease rates is identified. A positive correlation between lead exposure and infectious disease rates could have one of two interpretations. First, it might suggest that exposure to lead at a very young age undermined growth and development, leaving children especially vulnerable to subsequent exposure to childhood diseases like scarlet fever and measles. Second, a positive correlation might also

households. On the development of urban water systems, see Melosi (2000), p. 236; Tarr (1996), pp. 174-76; and Troesken (forthcoming), chapter 3. 
suggest that the use of lead water lines was, in fact, correlated with some unobserved variable like health-consciousness, and this variable, and not lead water lines per se, is what drove up infant mortality rates in towns with lead lines. A negative correlation between lead use and infectious disease rates would be consistent with the hypothesis that lead killed the weakest and most vulnerable children — children who would have inevitably died (without any lead poisoning) once they were exposed to illnesses of any serious magnitude.

Four childhood diseases are considered: diphtheria; measles; scarlet fever; and whooping cough. Table 6 reports the regression results. The first set of regressions are for a small sample of twenty-one towns for which there is data on the lead content of household tap water. For these twenty-one towns, there is weak evidence of a negative correlation between the lead content of tap water and infectious disease rates, particularly diphtheria. For the full sample of towns, there is weak evidence that the use of lead water lines was negatively correlated with deaths from infectious diseases, particularly whooping cough. The weak negative correlation between infectious disease rates and lead exposure suggests that at least some of the victims of fatal lead poisoning would have eventually died from diphtheria and other infectious diseases. Although it is important to stress that this negative correlation is not especially precise, or very large, the absence of any systematic evidence of a positive correlation between infectious disease rates and lead use undermines the idea that it was a lack of health consciousness, and not lead water mains directly, that drove up infant mortality rates.

\section{Controlling for Health Consciousness Directly}

In this section, health consciousness is controlled for directly. Table 7 reports the results for the regressions using direct controls. Regressions (1)-(3) use death rates from two childhood infectious diseases - measles and whooping — and age-specific death rates for older children to 
capture some of the effects of health consciousness. These regressions also include death rates for older-aged children as control variables. In towns with high levels of health awareness, it seems reasonable to assume that this awareness would have manifested itself in lower infectious disease rates. Based on the empirical work above, and the model developed in section IV, it is reasonable to assume that the death rates for older-aged children were correlated with deaths related to infectious diseases, but not to deaths related to lead poisoning. ${ }^{33}$

When these direct controls are added to the regressions, the coefficient on the lead water line dummy is reduced by half in the case of stillbirths, is reduced by about 20 percent in the case of infant deaths, and is unaffected in the case of deaths for children aged one to two. Nonetheless, the coefficient remains statistically significant at high levels for all three regressions, and the estimated effect of lead water lines is still quite large. In particular, regressions (1)-(3) suggest that, on average, lead water lines increased stillbirth rates by 23 percent, infant mortality rates by 31 percent, and the death rate among one- to two-year olds by 25 percent.

Regressions (4)-(6) add the following control variables: a dummy variable indicating whether the city used an underground water source (underground sources where much less polluted than above-ground sources); and a series of dummy variables indicating the development of the city's sewer system (no sewers is the omitted category). Presumably, towns that were highly health conscious would have been more likely to seek out purer water sources, and to develop more extensive sewer systems. ${ }^{34}$ Adding controls for the development of public infrastructure does not alter the findings reported in regressions (1)-(3) in any meaningful way. Furthermore, in two of the

\footnotetext{
${ }^{33}$ Dropping these older-age death rates from the regressions does not alter the findings.

${ }^{34}$ One might wonder about the endogeneity of the sewer system dummies. However, previously published work demonstrates that it is proper to treat sewers as exogenous determinants of disease rates (Troesken 2002).
} 
three regressions (the infant death rate, and the death rate for one-to-two year olds), adding controls for public infrastructure reduces the adjusted- $R^{2}$, suggesting that, collectively, these controls are not correlated with death rates for young children.

\section{E. Using Instrumental V ariables to Control for Unobserved Heterogeneity}

In this section, instrumental variables are used to control for unobserved heterogeneity. The estimation proceeds in two-stages. In the first stage, a probit model is estimated to predict lead use in each town. In the second stage, the predicted probability of lead use in each town is used as an explanatory variable in models of early childhood mortality. The procedure is described more fully in Maddala (1991, pp. 241-43).

Three instruments are used to predict lead use. The first instrument relates to the financing of service lines. In some instances, the water company paid for the installation of service lines. In other cases, the property owner assumed the full cost, or a substantial fraction of the cost. A dummy variable indicates whether property owners had to pay, in part or in full, for the installation of a service pipe (=1 if property owner paid; 0 if water company paid). This variable is referred to short hand as the "owner-pays dummy". For the sample used in this paper, in 23 percent of the towns, the water company assumed the full cost of installing the service line; in the remaining 77 percent, the property owner had to pay some or all of the cost. ${ }^{35}$

The theoretical justification for using the owner-pays dummy is that property owners and water companies had different time horizons and placed different values on the future benefits of a durable service pipe. These contrasting time horizons flowed from three sources. First, once a service pipe was installed, the property owner was typically responsible for maintaining and replacing

\footnotetext{
${ }^{35}$ There were eight towns for which it was not possible to directly identify who paid for the service line. Based on other information provided by Baker (1897), it is assumed that in all of these towns, the property owner paid, in part or in full, for the installation of the service line.
} 
the pipe if it ruptured. Second, if real-estate markets functioned well, the value of a durable service line would have been capitalized into the value of a home or rental property. Third, the rates local water companies charged for water were heavily regulated and were subject to political pressures from local voters and politicians. As a result of the first two factors, consumers would have placed a value on the durability of service lines, and would have been willing to pay for such durability. In contrast, because the rates local water companies charged for water were heavily regulated, it would have been difficult for water companies to fully capture the future benefits of long-lived service lines, unless they charged consumers directly for the installation of that line (and in which case the consumer-pays dummy would be coded as one). One, therefore, expects a positive correlation between the consumer-pays dummy and lead use. And in the raw data, this exactly what is observed: of the fourteen towns where the water company assumed all the costs of installing service pipes, only one (7 percent) used lead pipes; of the sixty towns where consumers paid for the service pipe, in part or in full, twenty-one (35 percent) used lead pipes.

The second instrument is the number of water meters per 100 miles of water mains. ${ }^{36}$ This variable reflects the density and complexity of urban infrastructure. The more water meters there were, the more complex the infrastructure, and the more desirable lead service pipes would have been. Because lead was soft and pliable, it allowed plumbers to bend and twist the pipe around existing fixtures. The meters-per-main variable also reflects the number of high volume water users in a community, because during this time, meters were mainly used for large-industrial customers; households typically paid for water on a fixed (zero-marginal cost) basis related to the number taps

${ }^{36}$ Baker (1897) provides the meters-per-main variable for sixty-two of the seventy-four cities in the sample. For the remaining twelve cities, meters-per-main has been estimated using a linear regression model relating the number of water meters to the number of fire hydrants and the number of water taps. 
contained in the home. The presence of large-industrial consumers, paying on a per unit basis for water might have allowed water companies to cross-subsidize small consumers, including providing them with more expensive and more durable service pipes. Peltzman (1971) shows, for example, that there are incentives for municipally-owned electric companies to charge large users relatively high rates in order to subsidize small-users, who are also voters. Based on this discussion, one expects meters-per-main to have been positively correlated with lead use. The raw data support this prediction: for towns using lead pipes, meters-per-main averaged 16.4, while in towns using non-lead pipes, meters-per-main averaged 11.7. (The difference is significant at the 13 percent level).

The third and final instrument relates to the ownership history of urban water systems. In turn-of-the-century Massachusetts, the ownership history of urban water systems fell into one of three categories: water companies that had always been public; companies that had always been private; or companies that were currently public but were once private. The companies of primary interest are those that experienced a change in ownership regime from private to public — in short, companies that had been "municipalized". Recent research shows that private water companies were generally municipalized, not because of concerns about public health or the exercise of monopoly power, but because they were valuable source of revenue and political employment for local politicians. The private water companies most at risk for such political expropriation anticipated expropriation, and adjusted their fixed investments accordingly. ${ }^{37}$

Following this evidence, if a private water company anticipated future expropriation of its system, holding everything else constant, it would have refrained from installing pipes that were made of expensive and highly durable materials like lead, and would have chosen instead, to install

${ }^{37}$ For evidence on these issues, see Troesken (1997), (1999a), (1999b), and Troesken and Geddes (forthcoming). 
cheaper, less durable pipes made of untreated iron or steel. If one uses the municipalization dummy as a measure of the ex ante risk of subsequent expropriation (it is a perfect indicator of the risk ex post), a negative correlation between the municipalization dummy and lead use is expected. Patterns in the raw data are consistent with this line of thought. Of the forty-four water companies in the sample that had always been publically-owned, 36 percent used lead service pipes; of the fourteen companies that had once been private, but were made public sometime before 1900, 21 percent used lead service pipes. (The difference is significant at the 15 percent level.)

Table 8 reports the results of the analysis employing instrumental variables. The first two regressions are for the first-stage probits. The marginal effect of each variable (rather than the formal coefficient) is reported. In the basic model, the only exogenous variables other than the instruments are typhoid rates and $\log$ of the population. In the full model, all of the exogenous variables reported in table 7 -including, age-specific death rates, cause-specific death rates, log of population, water source, and the sewer dummies — are included along with the instruments. In the first-stage probits, the owner-pays dummy and the municipalization dummy are highly significant, and have a large independent effect on the probability of lead use: having the property owner pay for the service line increased the probability of lead use by 30 to 43 percentage points, and a water system that had been municipalized was 24 to 34 percentage points less likely to have had lead service pipes. The basic model predicts that 33 percent of the sample would have used lead, while the full model predicts that 19 percent of the sample would have used lead. With observed lead use around 36 percent, the basic model appears to perform better, in terms of prediction, than does the full model.

Using instrumental variables weakens some results, but strengthens others. In particular, the coefficient on predicted lead use is not a significant correlate with the death rate for children aged 
one to two. However, the coefficient on predicted lead use is a significant correlate with the stillbirth rate and the infant mortality rate, and it is roughly twice the size of the coefficient on observed lead use in the comparable regression presented in tables 5 and 7. According to the estimates here, lead water pipes increased the infant rate by 227 to 289 deaths, or between 63 and 80 percent. As for stillbirths, lead pipes increased the stillbirth rate by 42 to 127 fetal deaths, or between 44 and 133 percent. These patterns suggest that if there were some sort of unobserved heterogeneity across towns using lead and non-lead pipes, this heterogeneity imparts a downward bias in the OLS estimates of the effects of lead use.

\section{F. Using Interaction Effects to Mimic Natural Experiments}

The empirical work in this section builds on two well-documented correlations: the tendency for soft water to dissolve more lead from the interior of pipes than hard water; and the tendency for new pipes to leach more lead into tap water than old lead pipes because oxidation has yet to form a protective barrier around the interior of new lead pipes. These correlations suggest that, holding everything else constant, lead water lines would have had a larger effect on infant mortality rates in towns with soft water (new lead pipes) than in towns with hard water (old lead pipes). Evidence that such interaction effects influenced infant mortality would be difficult to reconcile with stories about health consciousness and unobserved heterogeneity. For example, one might be able to construct an argument that hard water alone was correlated with both health consciousness and infant mortality. But to argue that, not only was there this correlation, but that it somehow differed across cities with lead water lines and non-lead lines, would require something more than a strained argument.

The results of these experiments are reported in table 9. In addition to the variables reported in the table, the regressions include the following control variables: the death rate for 
children aged two to four; the death rate for children aged four to ten; the death rate from typhoid fever; log of the town's population; and a dummy variable indicating if the town drew its water from an underground source. For hard water, the results suggest that hard water dissolved much less lead from the interior walls of lead pipes than did soft water, which is exactly what one would expect. Interacting the lead dummy with the measure of water hardness indicates that, holding everything else constant, towns with hard water and lead lines had significantly lower infant and young child mortality rates than did towns with soft water and lead pipes.

For towns with many newly installed water lines (defined as the proportion of water mains installed during the previous ten years), the results are again consistent with the predictions suggested by chemistry. Towns with lots of relatively new lead water lines had significantly higher infant mortality rates than did towns with few new lead lines. Indeed, once one enters the interaction effect, the dummy on lead lines alone is small and insignificant, suggesting that all of the effects of lead water lines on infant mortality are to be found in cities with relatively new water lines. The final three regressions in table 9 allow for a more complex interaction effect where proportion of newly installed mains has a larger effect in cities with populations greater than 60,000 than in smaller cities with new lead lines. Allowing for this more complex interaction effect strengthens the results. $^{38}$

There are two concerns surrounding this analysis of interaction effects. First, based on the raw regressions alone, it is difficult to assess the magnitude of these effects. Second, whenever one

${ }^{38}$ There is a theoretical motivation for allowing newly installed water mains to have a different effect in large cities than in small ones. Large cities tended to have higher population densities, and therefore an additional mile of mains in a large city probably implied a much larger addition to the water system, in terms of homes newly connected, than in a small city with lower population density. See also Troesken (2002) for evidence and a more thorough discussion of this issue. 
starts interacting variables with a small data set, degrees of freedom are quickly lost and it becomes unclear if the results are driven by only one or two observations. To address both of these concerns, the models specified above are made as parsimonious as possible, and the results are then plotted graphically. Aside from lead use and the hardness of local water supplies, the only control variable will be population.

Consider first, then, how the effects of lead water pipes varied with the hardness of a town's water supply. After restricting the sample to towns with populations greater than 12,000 persons, the infant mortality rate $\left(\mathrm{y}_{\mathrm{i}}\right)$ in each town is regressed against a measure of the hardness of the town's water supply. Running separate regressions for towns with lead and non-lead lines, the results are as follows:

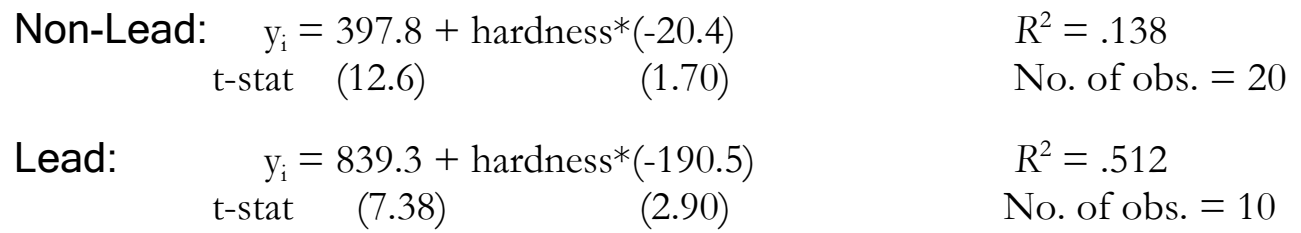

Figures 5 and 6 plot the data associated with these regressions, and the estimated trend lines. The y and $\mathrm{x}$ axes are scaled identically in both figures. Clearly, the relatively strong correlation between the hardness of local water supplies and infant mortality rates in cities with lead water lines is not driven by one or two observations. And in terms of magnitude, variation in hardness explains a large change in infant mortality rates — from a high of around 800 deaths per 100,000 persons for towns with soft water supplies, to a low of 250 deaths per 100,000 for towns with hard water supplies. ${ }^{39}$ Consider next, how the effects of lead water pipes varied with the age of local water lines.

\footnotetext{
${ }^{39}$ It should be noted that it is not surprising to see the hardness of local water supplies affect infant mortality rates in cities using non-lead service pipes. As explained in section II above, even without lead service lines, there would have been some lead elsewhere, though in much smaller amounts, in the interior plumbing of homes.
} 
After restricting the sample to towns with populations less than 60,000 persons, the infant mortality rate $\left(y_{i}\right)$ in each town is regressed against the proportion of the town's water mains that were installed during the previous ten years ( $\%$ new). Running separate regressions for towns with lead and non-lead lines, the results are as follows:

Non-Lead: $\quad \mathrm{y}_{\mathrm{i}}=357.4+(\% \text { new })^{*}(-68.2)$ t-stat (6.46) (0.26)

$$
\begin{aligned}
& R^{2}=.002 \\
& \text { No. of obs. }=42
\end{aligned}
$$

Lead:

$$
\begin{aligned}
& \mathrm{y}_{\mathrm{i}}= \\
& \mathrm{t} \text {-stat }
\end{aligned}
$$

$$
\begin{aligned}
& R^{2}=.555 \\
& \text { No. of obs. }=18
\end{aligned}
$$

Figures 7 and 8 plot the data associated with these regressions, and the estimated trend lines. The y axis is scaled identically in both figures. Clearly, the relatively strong correlation between (\%new) and infant mortality rates in cities with lead water lines is not driven by one or two observations. And in terms of magnitude, variation in (\%new) explains a large change in infant mortality rates-from a low of 150 deaths per 100,000 for cities with fewer than 10 percent newly- installed mains, to a high of 750 deaths per 100,000 for cities with 80 percent newly-installed mains.

\section{Conclusions}

The early-twentieth-century United States saw rapid improvements in life expectancy, and this improvement was especially pronounced in the heavily urbanized Northeast. Reductions in infant mortality account for most of the improvement in life expectancy (Haines 2001). The sources of the transition from high to low mortality, in the United States and elsewhere, have been the subject of extensive academic debates among demographers, economists, and historians. Typically, scholars emphasize one or more of the following three forces as the engine behind falling infant mortality. For some, it was the diffusion of the germ of the theory of disease to the general population. Increased knowledge of appropriate sanitary practices lead parents to adopt a variety of 
behaviors that helped protect infants, including breast-feeding, and boiling tap water. ${ }^{40}$ For others, it was investments in infrastructure related to public health, such as water purification systems and sewer systems, that helped protect infants. ${ }^{41}$ For still others, it was economic growth and the associated improvements in nutrition that explain the decline in infant mortality. ${ }^{42}$

The results of this paper suggest that historical demographers need to think about lead eradication, particularly as it relates to public water systems, as a source of improved infant mortality rates. In Massachusetts, the use of lead pipes to connect households to public water systems had enormous effects on infant mortality rates. In the typical Massachusetts city, lead pipes increased infant mortality rate by between 25 and 50 percent. And in towns with highly acidic water, or with relatively new lead pipes, the effects were even more dramatic, with lead pipes increasing infant death rates by factors as large as three or four. These findings are robust to reasonable changes in econometric specification, and in the case of the instrumental variables estimates, are made stronger by efforts to control for unobserved heterogeneity.

Although the engineers who designed public water systems were slow to acknowledge the dangers of lead water lines, over time municipalities began to abandon the practice of using lead pipes, and the lead pipes that remained gradually oxidized so that less lead was taken off the interior of the pipes. Moreover, by the 1930s, the federal government and some state governments were

${ }^{40}$ Studies emphasizing the increasing importance of the germ theory of disease over the course of the early twentieth century, include: Condran and Preston (1994); Ewbank and Preston (1990); Mokyr (2000); Preston and Haines (1991); Tomes (1998); and Wolf (2001).

${ }^{41}$ Studies emphasizing the importance of investments in public infrastructure related to health, include Condran and Crimmins-Gardner (1978); Fishback, Haines, and Kantor (2000); Higgs (1979); Meeker (1972) and (1976); Melosi (2000); Szreter (1997); and Tarr (1996).

${ }^{42}$ For studies exploring the role of nutrition, see, generally, Craig and Weiss (1998); Fogel (1986) and (2000), pp. 74-83; Fogel and Costa (1997); McKeown (1976); and Steckel (1995). 
actively regulating the amount lead that could be used in household plumbing systems. In Massachusetts, officials appear to have been even more aggressive and, as early as 1890, the State Board of Health was recommending that municipalities in the state abandon lead pipes. Similarly, in neighboring New Hampshire, public health officials began publicizing the dangers of lead service pipes during the early 1900s. According to one official, lead water pipes were abandoned "by the score" following investigations into the lead levels of New-Hampshire tap water (Howard 1923, p. 208):

As a result of these revelations, lead pipe systems were abandoned by the score, although always with more or less reluctance, the users being quick to recognize the superior merits of lead over iron, not only as to durability and ease of laying but as regards freedom from rusting, and in the tendency to deliver cleaner water.

Campaigns to eliminate lead pipes appear to have had a significant effect on the lead content of household tap water. Consider again the experience of New Hampshire. New Hampshire regularly sampled tap water from around the state for lead content. Table 10 reports the proportion of tap water sampled that contained lead in excess of .5 parts per million (ppm). During the two year period of 1909 and 1910, half of the nearly seven hundred samples of household tap water contained lead in excess of .5 ppm. By 1921-22, the proportion of samples with lead levels greater than .5 ppm was slightly less than 20 percent. Although by today's standards a lead level below .5 ppm it not especially praiseworthy-.5 ppm is 33 times the current EPA guideline of $.015 \mathrm{ppm}$ - the implied reduction in lead levels would have had a substantial effect on infant mortality rates. For example, the regression results reported in table 5 suggest that, in the typical city, reducing lead levels in tap water from $.75 \mathrm{ppm}$ to $.25 \mathrm{ppm}$ would have cut infant death rates by 16 percent. 


\section{References}

Baker, Moses N. 1897. The Manual of American Water-Works. New York: The Engineering News Publishing Company.

Buchanan, James and Gordon Tullock. 1962. The Calculus of Consent. Ann Arbor: The University of Michigan Press.

Charney, E., J.W. Sayre, and M. Coulter. 1980. "Increased Lead Absorption in Inner City Children: Where Does the Lead Come From?” Pediatrics, 65:226-31.

Centers for Disease Control and Prevention. 2001. "Fatal Pediatric Lead Poisoning-New Hampshire, 2000." Reported in the Journal of the American Medical Association. Volume 286. No. 1.

Cohen, N., D. Modai,. A. Golik, J. Weissgarten, S. Peller, A. Katz, Z. Averbukh, and U. Shaked. 1989. "Increased Concanavalin A-induced Suppressor Cell Activity in Humans With Occupational Lead Exposure." Environmental Research, 48:1-6.

Committee on Service Pipes. New England Water Works Association. Report of Committee on Service Pipes. Presented to the Association on March 14, 1917. Reprinted in the Journal of New England Water Works Association. Volume 31. No. 3. September 1917, pp. 323-389. Cited in text as CSP.

Condran, Gretchen A., and Eileen Crimmins-Gardner. 1978. "Public Health Measures and Mortality in U.S. Cities in the Late Nineteenth Century." Human Ecology, 6:27-54.

Condran, Gretchen A., and Samuel H. Preston. 1994. "Child Mortality Differences, Personal Health Care Practices, and Medical Technology: The United States, 1900-1930,” in Health and Social Change in International Perspective. Edited by Lincoln C. Chen, Arthur Kleinman, and Norma C. Ware. Boston: Harvard Series on Population and International Health.

Costa, D.L. 2000. "Understanding the Twentieth-Century Decline in Chronic Conditions Among Older Men." Demography, 37:53-72.

Craig, Lee A., and Thomas Weiss. 1998. "Nutritional Status and Agricultural Surpluses in the Antebellum United States," in The Biological Standard of Living in Comparative Perspective. Edited by John Komlos and Joerg Baten. Stuttgart: Franz Steiner Verlag.

Deppisch, L.M., J.A. Centeno, D.J. Gemmel, J. David, and N.L. Torres. 1999. “Andrew Jackson’s Exposure to Mercury and Lead: Poisoned President?" Journal of the American Medical Association, 282:569-71.

Downs, Anthony. 1957. An Economic Theory of Democracy. New York: Harper and Row.

Engineering News. Various issues. Cited in text as EN. 
Ewbank, Douglas C., and Samuel H. Preston. 1990. "Personal Health Behavior and the Decline of Infant and Child Mortality: The United States, 1900-1930," in What We Know about Health Transitions: The Social, Cultural, and Behavioral Determinants of Health. Volume 1. Edited by John Caldwell. Canberra: Health Transition Center, Australian National University.

Fishback, Price, Michael Haines, and Shawn Kantor. 2000. "The Impact of New Deal Programs on Black and White Infant Mortality in the South.” Explorations in Economic History, 38:93-122.

Fischbein, A., P. Tsang, J.J. Luo, J.P. Roboz, J.P. Jiang, and J.G. Bekesi. 1993. “The Immune System as Target for Subclinical Lead Related Toxicity." British Journal of Industrial Medicine, 50:185-86.

Fogel, Robert W. 1986. "Nutrition and the Decline in Mortality since 1700: Some Preliminary Findings," in Long-Term Factors in American Economic Growth. Edited by Stanley Engerman and Robert E. Gallman. Chicago: University of Chicago Press.

Fogel, Robert W. 2000. The Fourth Great Awakening and the Future of Egalitarianism. Chicago: University of Chicago Press. (Pp. 74-83).

Fogel, Robert W, and Dora L. Costa. 1997. "A Theory of Technophysio Evolution, with Some Implications for Forecasting Population, Health Care Costs, and Pension Costs." Demography, 34:49-66.

Haines, Michael R. 2001. “The Urban Mortality Transition in the United States, 1800-1940.” Historical Paper, \#134. National Bureau of Economic Research.

Higgs, Robert. 1979. "Cycles and Trends of Mortality in 18 Large American Cities, 1871-1900." Explorations in Economic History, 16:381-408.

Howard, Charles D. 1923. "Lead in Drinking Water." American Journal of Public Health, 13:207-09.

Jacobson, Louis S., Robert J. LaLonde, and Daniel G. Sullivan. 1993. "Earnings Losses of Displaced Workers." American Economic Review, 83:685-709.

Lanphear, B. and K.J. Rogham. 1997. "Pathways of Lead Exposure in Urban Children." Environmental Research, 74:67-73.

Maddala, G.S. 1991. Limited Dependent and Qualitative Variables in Econometrics. Cambridge: Cambridge University Press.

Markowitz, G. and D. Rosner. 2000. "“Cater to the Children': The Role of the Lead Industry in a Public Health Tragedy, 1900-1955.” American Journal of Public Health, 90:36-46.

Massachusetts. State Board of Health. Annual Reports. Various years, 1890-1900. Cited in text as $\mathrm{MSBH}$ 
Meeker, Edward. 1972. “The Improving Health of the United States, 1850-1915.” Explorations in Economic History, 9:353-73.

Meeker, Edward. 1976. “The Social Rate of Return on Investment in Public Health, 1880-1910.” Journal of Economic History, 34:392-421.

Melosi, Martin V. 2000. The Sanitary City: Urban Infrastructure from Colonial Times to the Present. Baltimore: The Johns Hopkins University Press.

McKeown, Thomas. 1976. The Modern Rise of Population. New York: Academic Press.

Milton News. Various issues.

Mokyr, Joel. 2000. “Why More Work for Mother?’ Knowledge and Household Behavior, 18701945." Journal of Economic History, 60:1-41.

Nebraska. Office of Epidemiology. 2001. Nebraska Epidemiology Report: Blood Lead Surveillance Data, 1999-2000.

Needleman, H.L. and D. Belinger. 1991. “The Health Effects of Low Level Exposure to Lead.” Annual Review of Public Health, 40:111-40.

Peltzman, Sam. 1971. "Pricing at Public and Private Enterprises: Electric Utilities in the United States." Journal of Law and Economics, 14:109-65.

Perazella, M.A. 1996. "Lead and the Kidney: Nephropathy, Hypertension, and Gout.” Connecticut Medicine, 60:521-26.

Pocock, Stuart J., Marjorie Smith, and Peter Baghurst. 1994. "Environmental Lead and Children's Intelligence: A Systematic Review of the Epidemiological Evidence.” British Medical Journal, 309-1189-97.

Preston, Samuel H. and Mich R. Haines. 1991. Fatal Years: Child Mortality in Late-Nineteenth Century America. Princeton: Princeton University Press.

Quam, G.N., and Arthur Klein. 1936. "Lead Pipes as a Source of Lead in Drinking Water." American Journal of Public Health, 26:778-80.

Ravin, J.G. and T.B. Ravin. 1999. "What Ailed Goya?” Journal of Ophthalmology, 44:163-70.

Sata, F., S. Araki, T. Tanigawa, Y. Morita, S. Sukurai, A. Nakata, and N. Katsuno. 1998. "Changes in T Cell Subpopulations in Lead Workers.” Environmental Research, 76:61-64.

Solliway, B.M., A. Schaffer, H. Pratt, S. Yannai. 1994. "A Multidisciplinary Study of Lead-Exposed Subjects." Environmental Research, 67:168-82. 
Steckel, Richard H. 1995. "Stature and the Standard of Living." Journal of Economic Literature, 33:1903-40.

Szreter, Simon. 1997. "Economic Growth, Disruption, Deprivation, Disease, and Death: On the Importance of the Politics of Public Health for Development." Population and Development Review, 23:693-728.

Tarr, Joel A. The Search for the Ultimate Sink: Urban Pollution in Historical Perspective. Akron: University of Akron Press.

Tomes, Nancy. 1998. The Gospel of Germs: Men, Women, and the Microbe in American Life. Cambridge: Harvard University Press.

Trepka, M.J., J. Heinrich, C. Krause, C. Schulz, U. Lippold, E. Meyer, and H.E. Wichman. 1997. "The Internal Burden of Lead Among Children in a Smelter Town-A Small Area Analysis." Environmental Research, 72:118-30.

Troesken, Werner. 1997. "The Sources of Public Ownership: Historical Evidence from the Gas Industry." Journal of Law, Economics, and Organization, 13:1-27.

Troesken, Werner. 1999a. "Patronage and Public-Sector Wages in 1896." Journal of Economic History, 59:424-46.

Troesken, Werner. 1999b. "Typhoid Rates and the Public Acquisition of Private Waterworks, 1880-1920." Journal of Economic History, 59:927-48.

Troesken, Werner. 2002. "The Limits of Jim Crow: Race and the Provision of Water and Sewerage Services in American Cities, 1880-1925.” Journal of Economic History, 62:734-772.

Troesken, Werner. Forthcoming. Water, Race, and Disease. Cambridge: MIT Press.

Troesken, Werner, and Patty Beeson. Forthcoming. "On the Significance of Lead Water Mains in American Cities: Some Historical Evidence," in Health and Labor Force Participation over the Life Course. Edited by Dora L. Costa. Chicago: University of Chicago Press and NBER.

Troesken, Werner, and Rick Geddes. Forthcoming. "Municipalizing American Waterworks, 1897 1915.” Journal of Law, Economics, and Organization.

United States. Department of the Interior. 1890 Census. Various volumes. Washington, D.C.: Government Printing Office.

United States. Environmental Protection Agency. Office of Water. 2000. Lead in Your Drinking Water. (http://www.epa.gov/safewater/Pubs/lead1.html).

United States. Department of Labor. Bureau of Labor Statistics. 1919. Women in the Lead Industries. By Alice Hamilton. Bulletin No. 253. Washington, DC: Government Printing Office. 
Warren, Christian. 2000. Brush with Death: A Social History of Lead Poisoning. Baltimore: Johns Hopkins University Press.

Wisconsin. Department of Natural Resources. 1993. Lead in Drinking Water. (http://www.dnr. state.wi.us/org/water/dwg/lead.html).

Wolf, Jacqueline H. 2001. Don't Kill Your Baby: Public Health and the Decline of Breastfeeding in the 19 and $20^{\text {th }}$ Centuries. Columbus: The Ohio State University Press.

Wolpaw Reyes, Jessica. 2003. "The Impact of Prenatal Lead Exposure on Infant Health.” Department of Economics. Amherst College.

Xintaras, C. 1992. Analysis Paper: Impact of Lead-Contaminated Soil on Public Health. U.S. Department of Health and Human Services. Agency for Toxic Substances and Disease Registry. Atlanta, GA. (http://www.atsdr.cdc.gov/exlead.html). 
Table 1. Lead Use and City Size

\begin{tabular}{lcrrr}
\hline & & \multicolumn{3}{c}{ Cities using } \\
\cline { 3 - 5 } City size in 1900 & no. of cities & only lead & lead \& other & no lead \\
\hline Population $>300,000$ & 16 & $8(50 \%)$ & $7(44 \%)$ & $1(16 \%)$ \\
$30,000<$ Pop $<300,000$ & 107 & $55(51 \%)$ & $22(21 \%)$ & $30(28 \%)$ \\
$8,000<$ Pop $<30,000$ & 156 & $46(29 \%)$ & $36(23 \%)$ & $74(47 \%)$ \\
Population $<8,000$ & 518 & $100(19 \%)$ & $72(14 \%)$ & $346(67 \%)$ \\
All towns and cities & 797 & $209(26 \%)$ & $137(17 \%)$ & $451(57 \%)$ \\
\hline
\end{tabular}

Source: Troesken and Beeson (forthcoming) 
Table 2. The Lead Content of Massachusetts Tap Water

\begin{tabular}{|c|c|c|c|c|c|c|c|c|}
\hline \multirow[b]{3}{*}{ Municipality } & \multicolumn{4}{|c|}{ Lead content of water after ${ }^{a}$} & \multicolumn{4}{|c|}{$(\text { Content)/(EPA level })^{\mathrm{b}}$} \\
\hline & \multicolumn{2}{|c|}{ ordinary use } & \multicolumn{2}{|c|}{ standing } & \multicolumn{2}{|c|}{ use } & \multicolumn{2}{|c|}{ standing } \\
\hline & $\max$ & ave. & $\max$ & ave. & $\max$ & ave. & $\max$ & ave. \\
\hline Andover & .0171 & .0108 & .0571 & .0257 & 11.4 & 7.2 & 38.1 & 17.3 \\
\hline Attleborough & .1714 & .0697 & .1371 & .0905 & 114.3 & 46.5 & 91.4 & 60.3 \\
\hline Beverly & .0257 & .0087 & .0314 & .0147 & 17.1 & 5.8 & 20.9 & 9.8 \\
\hline Bridgewater & .0086 & .0057 & .0171 & .0143 & 5.7 & 3.8 & 11.4 & 9.5 \\
\hline Brookline & .0114 & .0074 & .0286 & .0197 & 7.6 & 4.9 & 19.1 & 13.1 \\
\hline Cambridge & .0086 & .0025 & .0114 & .0064 & 5.7 & 1.7 & 7.6 & 4.3 \\
\hline Cohasset & .0086 & .0048 & .0086 & .0043 & 5.7 & 3.2 & 5.7 & 2.9 \\
\hline Dedham & .0100 & .0082 & .0200 & .0150 & 6.7 & 5.5 & 13.3 & 10.0 \\
\hline Grafton & .0229 & .0187 & .0457 & .0329 & 15.3 & 12.5 & 30.5 & 21.9 \\
\hline Hyde Park-new & .0457 & .0172 & .4571 & .0329 & 30.5 & 11.6 & 304.7 & 21.9 \\
\hline Hyde Park-old & .0200 & .0400 & .0457 & .3029 & 13.3 & 26.7 & 30.5 & 201.9 \\
\hline Lawrence & .1371 & .0543 & .1829 & .0704 & 91.4 & 36.2 & 121.9 & 46.9 \\
\hline Lowell-Blvd & .0800 & .0202 & .4000 & .0861 & 53.3 & 13.5 & 266.7 & 57.4 \\
\hline Lowell-Cook & .5143 & .1608 & .4643 & .2535 & 342.9 & 107.2 & 309.5 & 169.0 \\
\hline Metropolitan & .0400 & .0111 & .1371 & .0293 & 26.7 & 7.4 & 91.4 & 19.5 \\
\hline Middleborough & .3429 & .1549 & 1.1429 & .6171 & 228.6 & 103.3 & 761.9 & 411.4 \\
\hline Needham & .0171 & .0091 & .0429 & .0269 & 11.4 & 6.1 & 28.6 & 17.9 \\
\hline Newton & .0714 & .0432 & .1714 & .0908 & 47.6 & 28.8 & 114.3 & 60.5 \\
\hline North Attleboro & .0071 & .0049 & .0329 & .0226 & 4.7 & 3.3 & 21.9 & 15.1 \\
\hline Webster & .0200 & .0100 & .0571 & .0286 & 13.3 & 6.7 & 38.1 & 19.1 \\
\hline Wellesley & .0152 & .0101 & .0314 & .0219 & 10.1 & 6.7 & 20.9 & 14.6 \\
\hline Weymouth & .0800 & .0314 & .2286 & .1167 & 53.3 & 20.9 & 152.4 & 77.8 \\
\hline Mean & .0761 & .0320 & .1705 & .0874 & 50.7 & 21.3 & 113.7 & 58.3 \\
\hline Median & .0229 & .0110 & .0571 & .0290 & 15.3 & 7.3 & 38.1 & 19.3 \\
\hline No. of obs. & 22 & 22 & 22 & 22 & 22.0 & 22.0 & 22.0 & 22.0 \\
\hline
\end{tabular}

Notes:

a - lead content is measured as parts of lead per 100,000 units of water. Ordinary use indicates lead content of tap water after running the water for a few minutes; standing indicates lead content after allowing the water to stand in pipes overnight. The lead levels reported here were based on repeated sample. The column labeled max. indicates the maximum lead level observed after sampling; the column labeled ave. indicates the average lead level observed after repeated sampling.

b - current EPA standards allow water to contain .0015 parts of lead per 100,000. The columns divide the lead levels observed in Massachusetts by this modern standard.

Source: Massachusetts State Board of Health (1900), pp. 490-493. 
Table 3. Lead Content and the Chemical Composition of Local Water Supplies

\begin{tabular}{|c|c|c|c|c|c|}
\hline \multirow[b]{2}{*}{ Variable } & \multirow{2}{*}{$\begin{array}{c}\text { mean } \\
\text { (std dev) }\end{array}$} & \multicolumn{2}{|c|}{ Ordinary use } & \multicolumn{2}{|c|}{ Standing } \\
\hline & & (1) & $(2)$ & (3) & (4) \\
\hline $\begin{array}{l}\text { Lead content: } \\
\text { after ordinary use } \mathrm{e}^{\mathrm{a}}\end{array}$ & $\begin{array}{c}.032 \\
(.044)\end{array}$ & $\begin{array}{l}\text { dep. } \\
\text { var. }\end{array}$ & $\begin{array}{l}\text { dep. } \\
\text { var. }\end{array}$ & $\cdots$ & $\cdots$ \\
\hline $\begin{array}{l}\text { Lead content: } \\
\text { after standing overnight }\end{array}$ & $\begin{array}{c}.087 \\
(.141)\end{array}$ & $\ldots$ & $\ldots$ & $\begin{array}{l}\text { dep. } \\
\text { var. }\end{array}$ & $\begin{array}{l}\text { dep. } \\
\text { var. }\end{array}$ \\
\hline Free $\mathrm{CO}_{2}$ content ${ }^{\mathrm{c}}$ & $\begin{array}{c}1.721 \\
(1.097)\end{array}$ & $\begin{array}{l}.031^{\star} \\
(.007)\end{array}$ & $\begin{array}{l}.031^{\star} \\
(.009)\end{array}$ & $\begin{array}{l}.097^{*} \\
(.023)\end{array}$ & $\begin{array}{l}.097^{\star} \\
(.042)\end{array}$ \\
\hline Hardness $^{\mathrm{d}}$ & $\begin{array}{l}2.600 \\
(1.416)\end{array}$ & $\begin{array}{l}-.010^{\star} \\
(.006)\end{array}$ & $\begin{array}{l}-.010^{*} \\
(.004)\end{array}$ & $\begin{array}{l}-.025^{*} \\
(.018)\end{array}$ & $\begin{array}{l}-.025 \\
(.019)\end{array}$ \\
\hline Constant & & $\begin{array}{c}.004 \\
(.016)\end{array}$ & $\begin{array}{c}.004 \\
(.013)\end{array}$ & $\begin{array}{l}-.015 \\
(.053)\end{array}$ & $\begin{array}{l}-.015 \\
(.046)\end{array}$ \\
\hline Robust standard errors & & no & yes & no & yes \\
\hline Adjusted-R2 & & .437 & .522 & .419 & .474 \\
\hline Number of observations & 22 & 22 & 22 & 22 & 22 \\
\hline
\end{tabular}

Notes:

a, b - lead content is measured as parts of lead per 100,000 units of water. Ordinary use indicates lead content of tap water after running the water for a few minutes; standing indicates lead content after allowing the water to stand in pipes overnight.

${ }^{\mathrm{c}}$ - free carbon dioxide mixed with water creates carbonic acid; the more carbon dioxide there is, the more acid there is. Free carbon dioxide is positively correlated with the acidity of water.

d - hardness is a positive function of the amount of magnesium and calcium in the water. Hard water was typically less corrosive than soft water, after controlling for the amount of free-carbon dioxide.

* - significant at the 5 percent level or higher (one-tailed test).

Source: Based on data from the Massachusetts State Board of Health (1900), pp. 490-493. See text. 
Table 4. Summary Statistics

\begin{tabular}{lccccccc}
\hline & \multicolumn{3}{c}{ Unweighted sample } & & \multicolumn{3}{c}{ Weighted samples } \\
\cline { 2 - 5 } \cline { 7 - 8 } Variable & full & lead & no lead & & full & lead & no lead \\
\hline Stillbirths per 100,000 & 94.6 & 106.5 & 89.8 & & 121.9 & 163.1 & 95.9 \\
persons & $(56.5)$ & $(76.3)$ & $(45.7)$ & & $(76.5)$ & $(102.7)$ & $(36.4)$ \\
Death rate: children & 349.4 & 368.8 & 341.2 & & 425.3 & 523.6 & 363.0 \\
0-1 years old & $(159.1)$ & $(216.7)$ & $(129.1)$ & & $(170.2)$ & $(209.2)$ & $(102.1)$ \\
Death rate: all persons & 1151.7 & 1171.6 & 1143.7 & & 1119.9 & 1108.8 & 1125.0 \\
older than age 10 & $(261.7)$ & $(252.6)$ & $(267.3)$ & & $(182.8)$ & $(161.5)$ & $(194.6)$ \\
Population in 000s, & 21.7 & 28.3 & 18.9 & & 50.4 & 57.0 & 46.2 \\
1900 & $(25.1)$ & $(29.2)$ & $(22.9)$ & & $(37.0)$ & $(35.0)$ & $(38.0)$ \\
Typhoid: deaths per & 19.7 & 16.7 & 21.0 & & 21.2 & 19.3 & 22.4 \\
100,000 persons & $(17.5)$ & $(13.5)$ & $(19.0)$ & & $(12.9)$ & $(9.58)$ & $(14.6)$ \\
$=1$ if lead water pipes & .297 & $\ldots$ & $\ldots$ & & .388 & $\ldots$ & $\ldots$ \\
& & & & & & \\
Hardness of water & 1.85 & 1.56 & 1.97 & & 1.61 & 1.40 & 1.74 \\
& $(1.56)$ & $(1.16)$ & $(1.69)$ & & $(1.29)$ & $(.797)$ & $(1.52)$ \\
\% of all water mains & .209 & .229 & .199 & & .222 & .229 & .218 \\
installed $<10$ yr's old & $(.107)$ & $(.137)$ & $(.089)$ & $(.105)$ & $(.113)$ & $(.101)$ \\
No. of observations & 74 & 22 & 52 & 74 & 22 & 52 \\
\hline
\end{tabular}

Notes:

a - number of infant deaths per 100,000 persons.

b - number of deaths among persons aged ten or older per 100,000 persons.

The weighted sample gives towns with larger populations more weight than towns with small populations. This is done to control for the possibility that death rates were measured with greater accuracy in large towns than in small ones. In particular, all regressions are estimated using STATA (7.0) and the data are weighted according to the aweights algorithm. This weighting scheme uses weights that are inversely proportional to the variance of an observation so that the variance of the jth observation is assumed to be $F^{2} / w_{j}$, where $w_{j}$ is the weight of the $j$ th observation.

Sources: see text. 


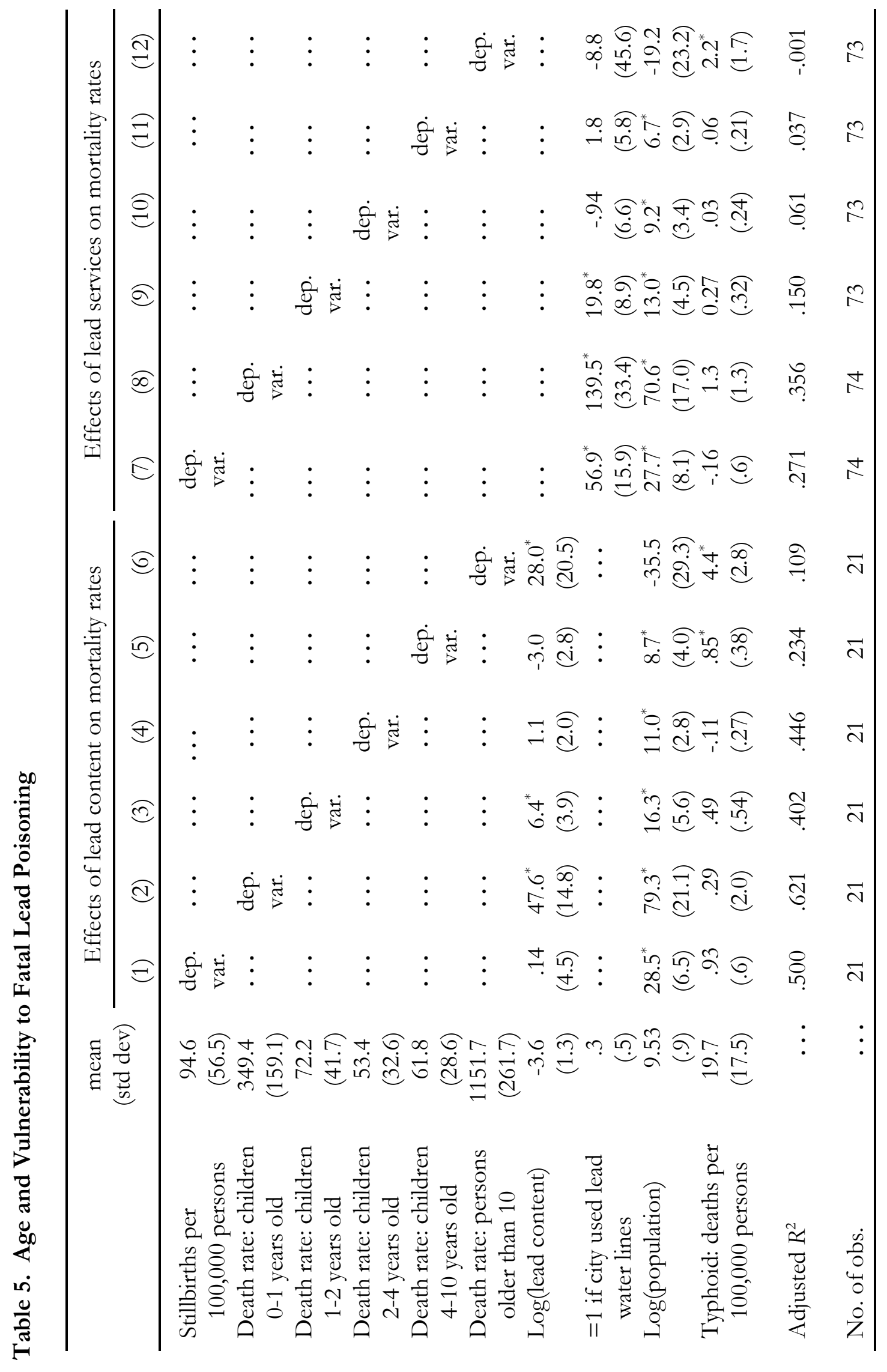




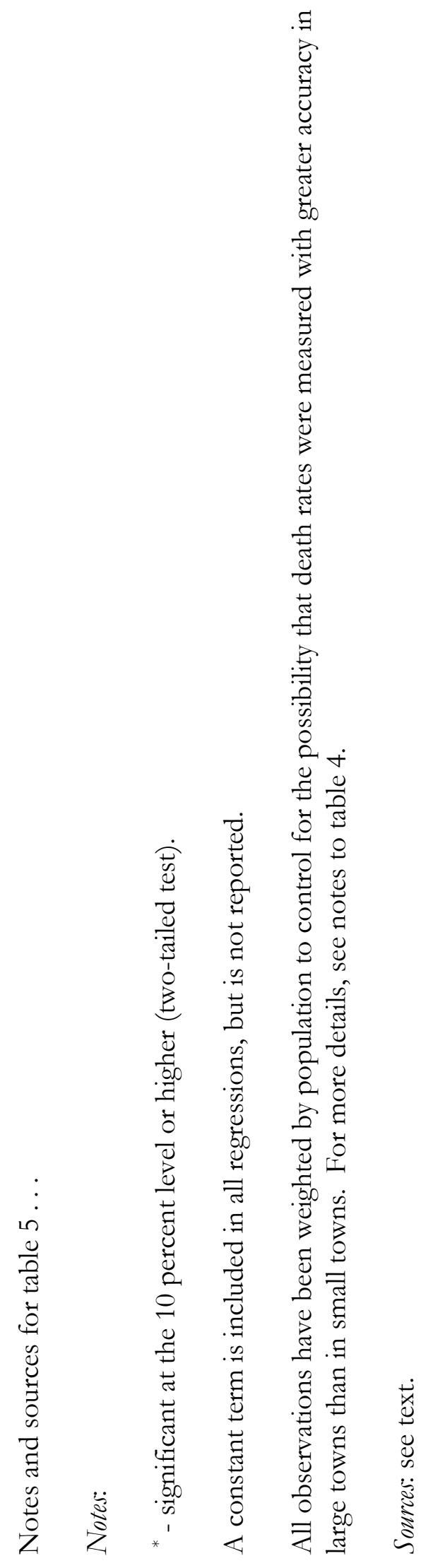




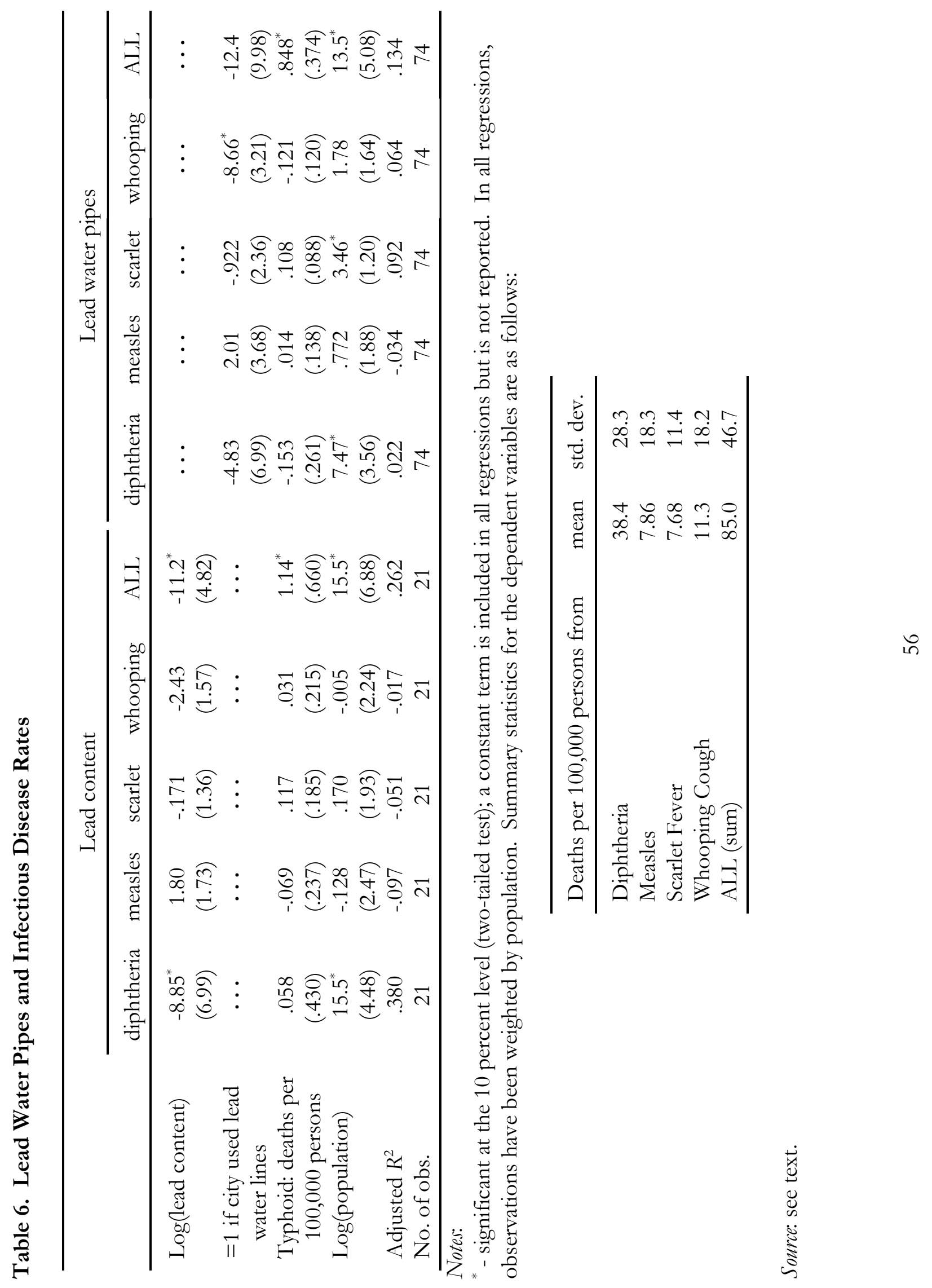


Table 7. Controlling for Health Consciousness Directly

\begin{tabular}{|c|c|c|c|c|c|c|}
\hline \multirow[b]{2}{*}{ Variable } & \multicolumn{3}{|c|}{ Age \& infectious diseases } & \multicolumn{3}{|c|}{ Plus public infrastructure } \\
\hline & $(1)$ & $(2)$ & (3) & (4) & (5) & (6) \\
\hline $\begin{array}{l}\text { stillbirths per } \\
100,000 \text { persons }\end{array}$ & $\begin{array}{l}\text { dep. } \\
\text { var. }\end{array}$ & $\cdots$ & $\cdots$ & $\begin{array}{l}\text { dep. } \\
\text { var. }\end{array}$ & $\cdots$ & $\cdots$ \\
\hline $\begin{array}{l}\text { death rate: children } \\
0-1 \text { years old }\end{array}$ & $\ldots$ & $\begin{array}{l}\text { dep. } \\
\text { var. }\end{array}$ & $\ldots$ & $\ldots$ & $\begin{array}{l}\text { dep. } \\
\text { var. }\end{array}$ & $\ldots$ \\
\hline $\begin{array}{l}\text { death rate: children } \\
1-2 \text { years old }\end{array}$ & $\cdots$ & $\ldots$ & $\begin{array}{l}\text { dep. } \\
\text { var. }\end{array}$ & $\cdots$ & $\ldots$ & $\begin{array}{l}\text { dep. } \\
\text { var. }\end{array}$ \\
\hline death rate: children & .127 & $2.35^{*}$ & $.369^{*}$ & .186 & $2.37^{*}$ & $.378^{*}$ \\
\hline 2-4 years old & $(.238)$ & $(.687)$ & $(.160)$ & $(.243)$ & $(.711)$ & $(.166)$ \\
\hline death rate: children & .256 & -.801 & .172 & .249 & -.781 & $.195^{*}$ \\
\hline 4-10 years old & $(.212)$ & $(.609)$ & $(.142)$ & $(.215)$ & $(.631)$ & $(.147)$ \\
\hline typhoid: deaths per & .367 & $1.95^{*}$ & .285 & .401 & $1.85^{*}$ & .289 \\
\hline 100,000 persons & $(.327)$ & $(.941)$ & $(.219)$ & $(.336)$ & $(.985)$ & $(.230)$ \\
\hline measles: deaths per & .574 & 1.57 & $.962^{*}$ & .359 & 1.54 & $.967^{*}$ \\
\hline 100,000 persons & $(.401)$ & $(1.15)$ & $(.268)$ & $(.423)$ & $(1.24)$ & $(.289)$ \\
\hline whooping cough: & -.130 & .799 & $.388^{*}$ & -.067 & .406 & .283 \\
\hline deaths per 100,000 & $(.350)$ & $(1.01)$ & $(.235)$ & $(.380)$ & $(1.11)$ & $(.260)$ \\
\hline $\log ($ population $)$ & 8.29 & $34.3^{*}$ & $6.97^{*}$ & 3.44 & $30.9^{*}$ & $8.16^{*}$ \\
\hline & $(4.95)$ & $(14.2)$ & $(3.32)$ & $(6.06)$ & $(17.7)$ & $(4.14)$ \\
\hline $\begin{aligned}= & 1 \text { if underground } \\
& \text { water source }\end{aligned}$ & $\cdots$ & $\ldots$ & $\ldots$ & $\begin{array}{l}-11.9 \\
(10.2)\end{array}$ & $\begin{array}{l}-43.9^{*} \\
(30.1)\end{array}$ & $\begin{array}{l}-5.48 \\
(7.01)\end{array}$ \\
\hline $\begin{aligned}= & 1 \text { if city had storm } \\
& \text { sewers }\end{aligned}$ & $\cdots$ & $\cdots$ & & $\begin{array}{l}-19.9 \\
(19.4)\end{array}$ & $\begin{array}{l}-3.01 \\
(56.8)\end{array}$ & $\begin{array}{c}16.7 \\
(13.3)\end{array}$ \\
\hline $\begin{aligned}= & 1 \text { if city had some } \\
& \text { sanitary sewers }\end{aligned}$ & $\cdots$ & $\cdots$ & $\cdots$ & $\begin{array}{l}-20.0 \\
(25.9)\end{array}$ & $\begin{array}{c}48.7 \\
(75.8)\end{array}$ & $\begin{array}{c}15.4 \\
(17.7)\end{array}$ \\
\hline $\begin{aligned}= & 1 \text { if city had sanitary } \\
& \text { sewers }\end{aligned}$ & $\cdots$ & $\cdots$ & $\cdots$ & $\begin{array}{l}-24.0^{*} \\
(16.6)\end{array}$ & $\begin{array}{l}-19.6 \\
(48.6)\end{array}$ & $\begin{array}{l}-.100 \\
(11.3)\end{array}$ \\
\hline $\begin{aligned}= & 1 \text { if both sanitary } \\
& \text { and storm sewers }\end{aligned}$ & $\cdots$ & $\cdots$ & $\cdots$ & $\begin{array}{c}-3.8 \\
(14.6)\end{array}$ & $\begin{array}{l}-1.68 \\
(42.8)\end{array}$ & $\begin{array}{c}2.72 \\
(9.99)\end{array}$ \\
\hline $\begin{array}{l}=1 \text { if city used lead } \\
\text { water lines }\end{array}$ & $\begin{array}{l}21.7^{*} \\
(9.68)\end{array}$ & $\begin{array}{l}112.3^{*} \\
(27.9)\end{array}$ & $\begin{array}{r}21.2^{*} \\
(6.49)\end{array}$ & $\begin{array}{l}21.4^{*} \\
(10.1)\end{array}$ & $\begin{array}{l}114.7^{*} \\
(29.7)\end{array}$ & $\begin{array}{l}21.7^{*} \\
(6.93)\end{array}$ \\
\hline Adjusted $R^{2}$ & .225 & .509 & .612 & .237 & .499 & .603 \\
\hline No. of obs. & 73 & 73 & 73 & 73 & 73 & 73 \\
\hline
\end{tabular}

Notes: ${ }^{*}$ - significant at the ten percent level or higher (one-tailed test). A constant term is included in all regressions but is not reported. All observations have been weighted by population.

Source: see text. 


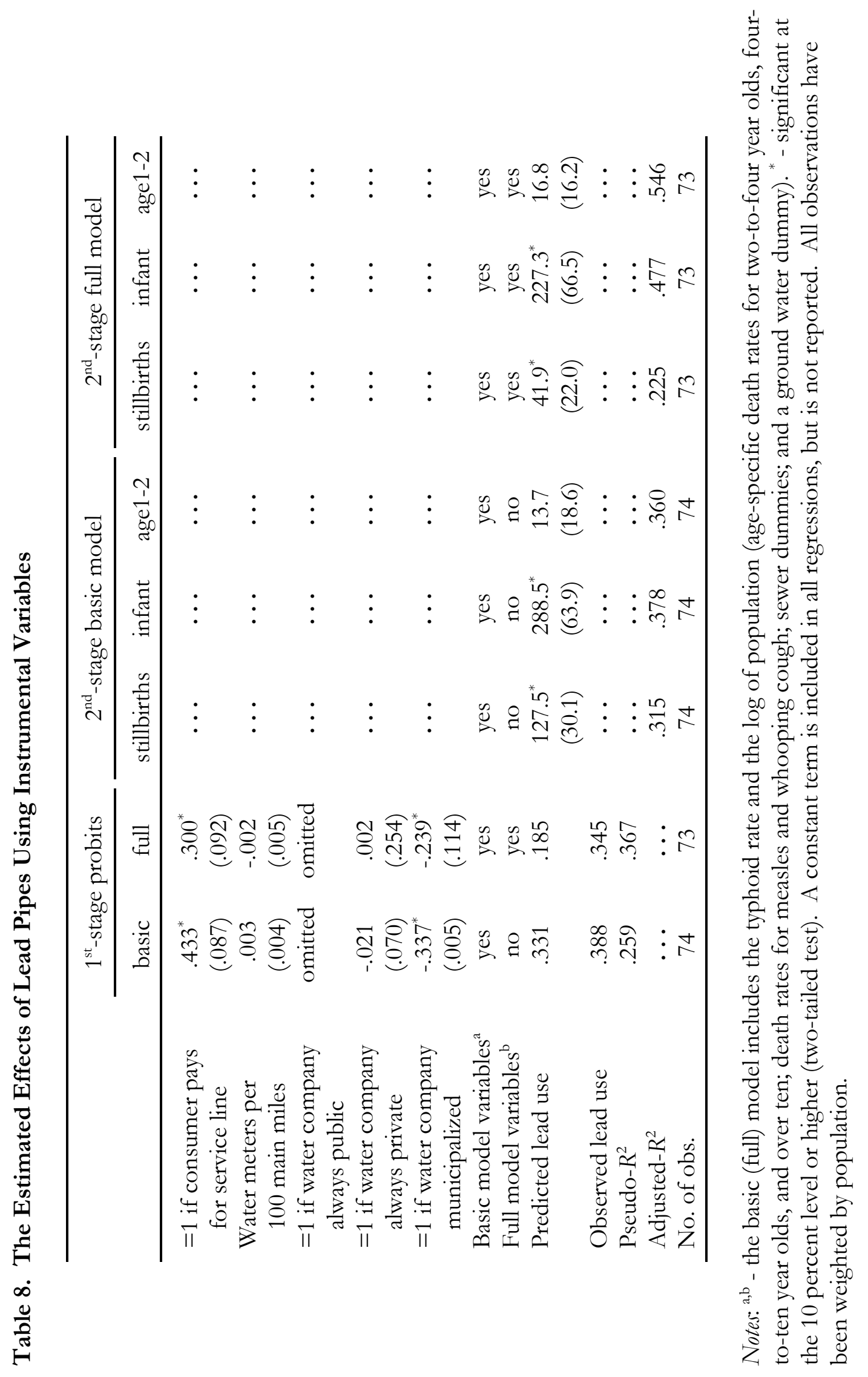




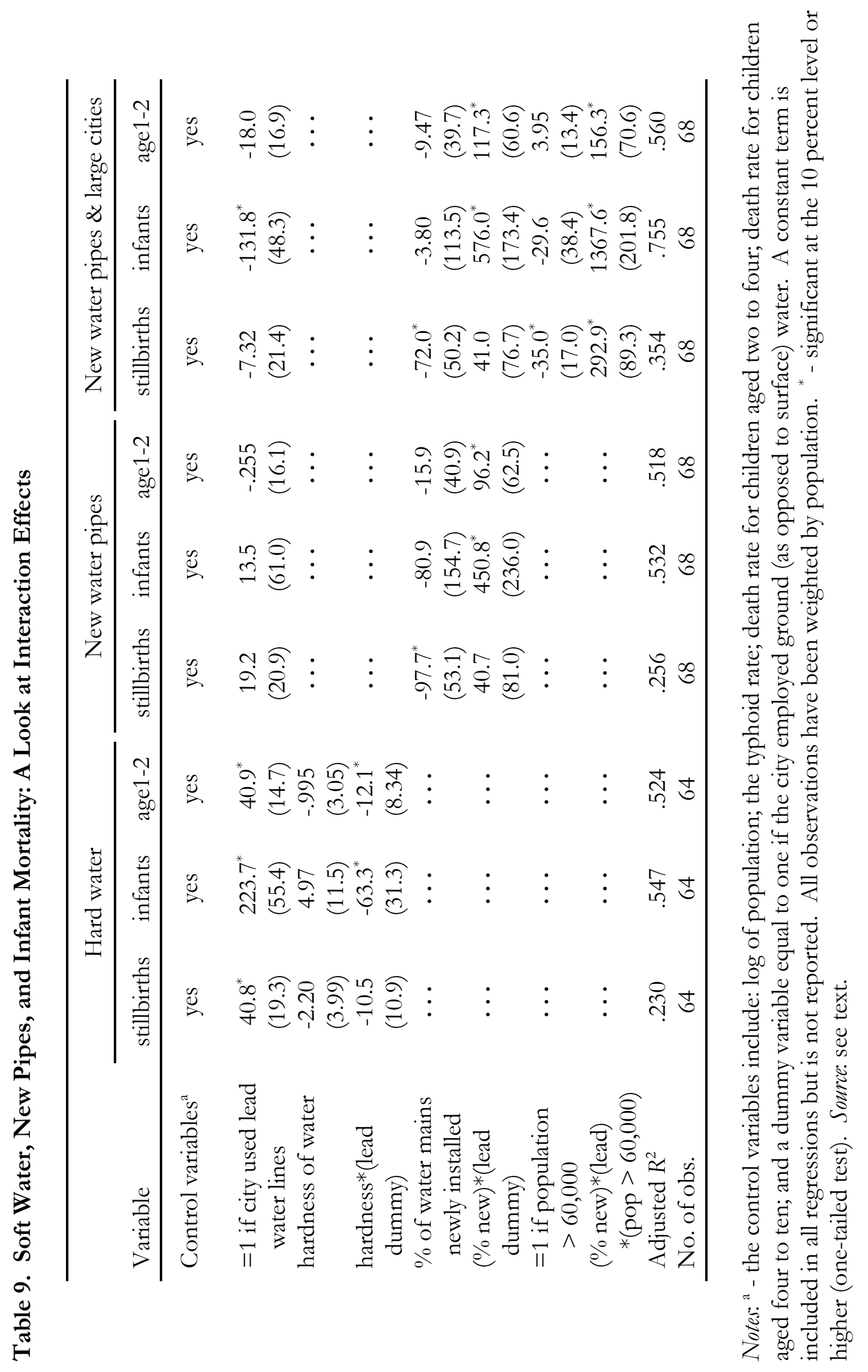

กิ 
Table 10. Lead Content in New Hampshire Tap Water, 1909-1922

\begin{tabular}{lcc}
\hline Period & Number of samples & $\% \mathrm{w} /$ lead content $>.5$ parts per million \\
\hline $1909-10$ & 699 & 49.5 \\
$1911-12$ & 677 & 39.0 \\
$1913-14$ & 632 & 45.0 \\
$1915-16$ & 581 & 33.2 \\
$1917-18$ & 371 & 24.0 \\
$1919-20$ & 439 & 21.4 \\
$1921-22$ & 380 & 18.7 \\
\hline
\end{tabular}

Source: Howard (1923). 


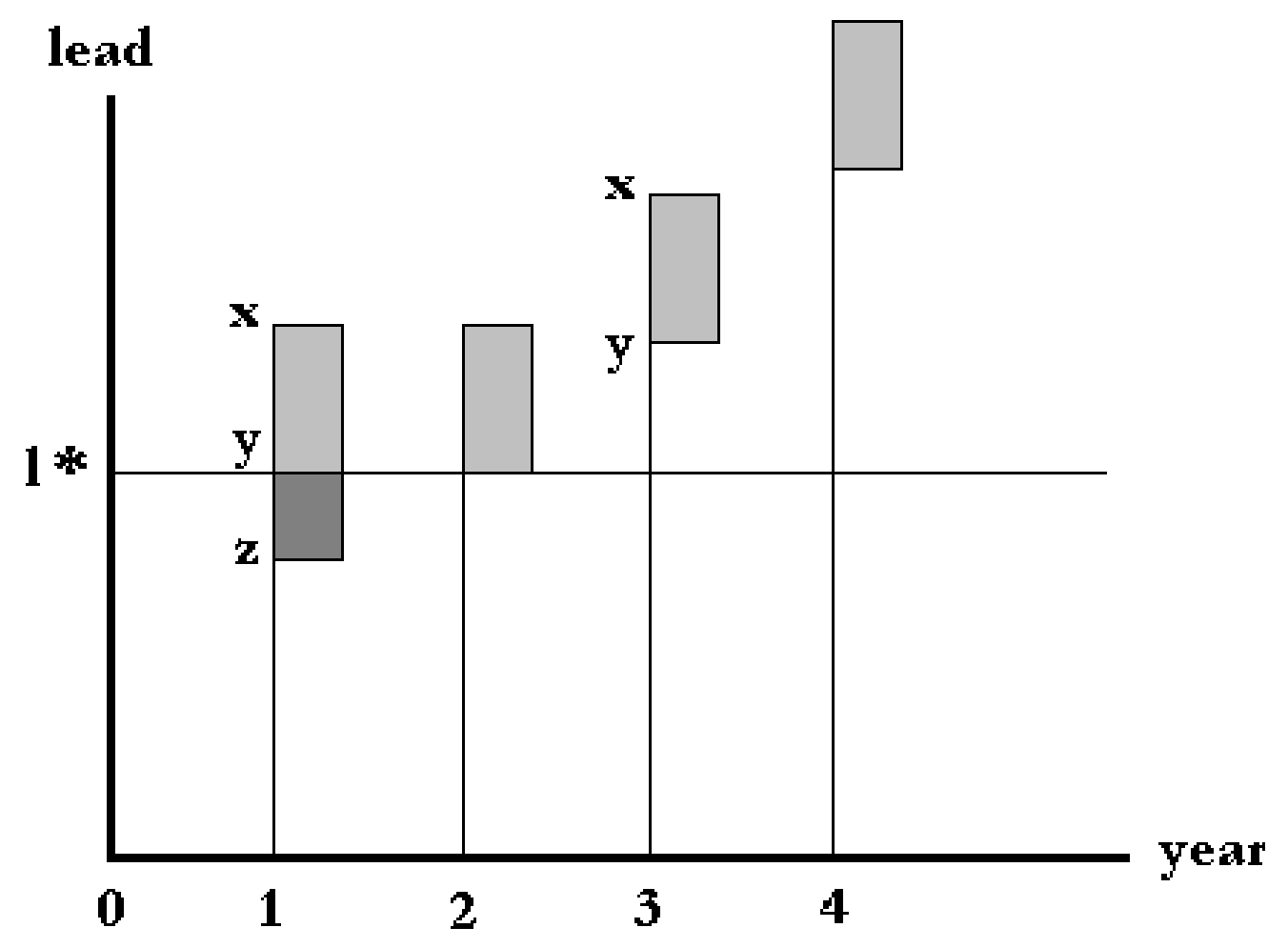

Figure 1. Lead Exposure Over Time for One Birth Cohort.

Notes: this figure follows a hypothetical birth cohort over four year time span, from year 0 (birth) up to the beginning of year 4. Lead exposure remains constant at $l^{*}$ for this cohort. The ability to withstand lead is uniformly distributed for this cohort. In year 1, the distribution is defined by XYZ, with all persons below $Y$, dying from lead poisoning. Once the part of the population most vulnerable to lead poisoning has died, there are no deaths from lead poisoning. The ability to withstand lead poisoning improves as the birth cohort matures and grows, and this is reflected in the upward movement in the distribution $X Y$.

Source: see text. 


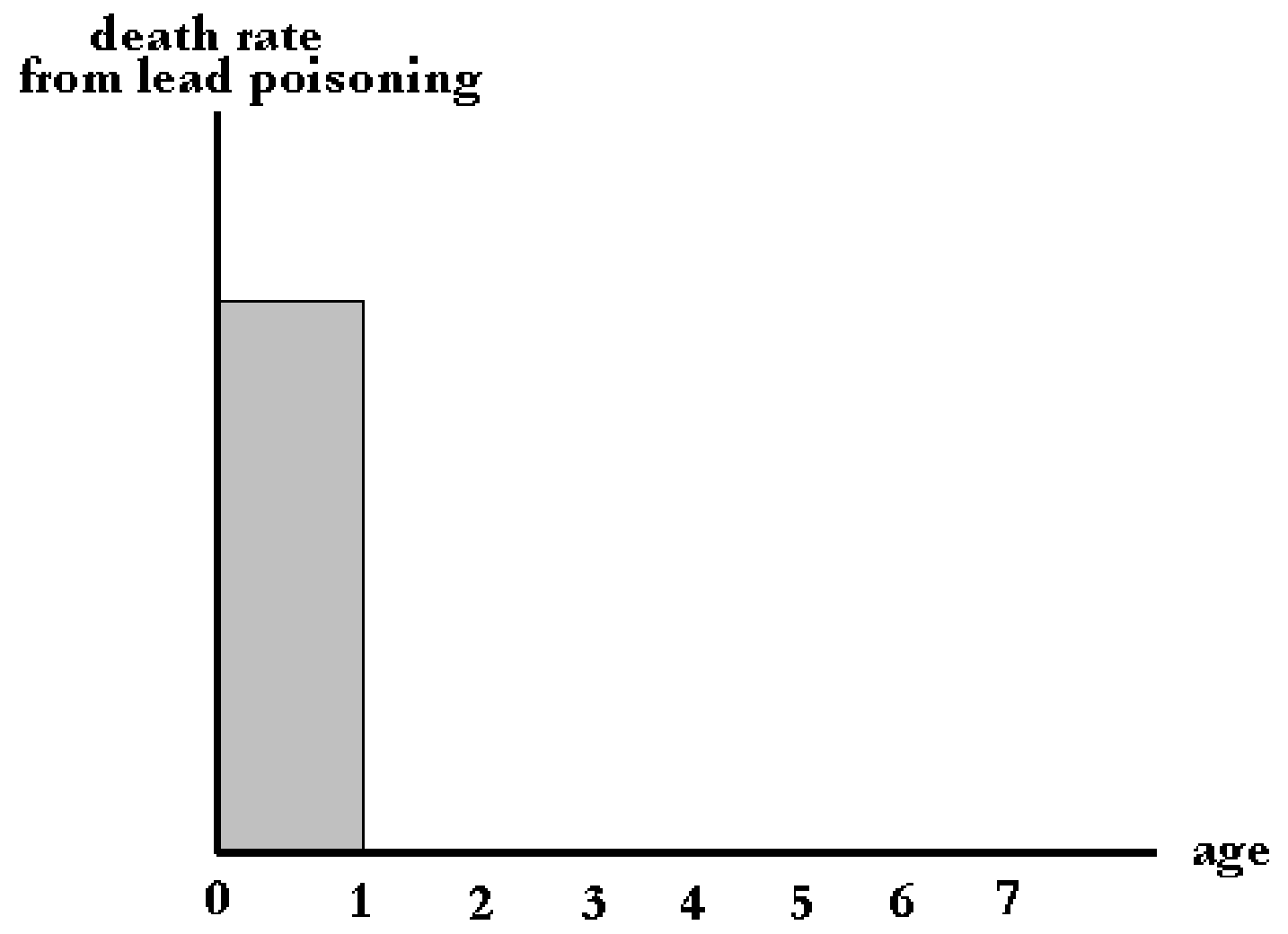

Figure 2. Lead-Related Death Rates by Age: One Plausible Scenario

Notes: the scenario sketched out in figure 1 implies that all lead related deaths would occur during the first year life, and fall to zero in subsequent years. The exact structure of this profile is, of course, an empirical matter. But the basic point is that nearly all lead related deaths will occur during an early life stage, and fall to zero once those persons most vulnerable to lead poisoning were eliminated from the population. The drop-off might occur at six months or two-years. This assumes that lead exposure remains constant over time.

Source: see text. 


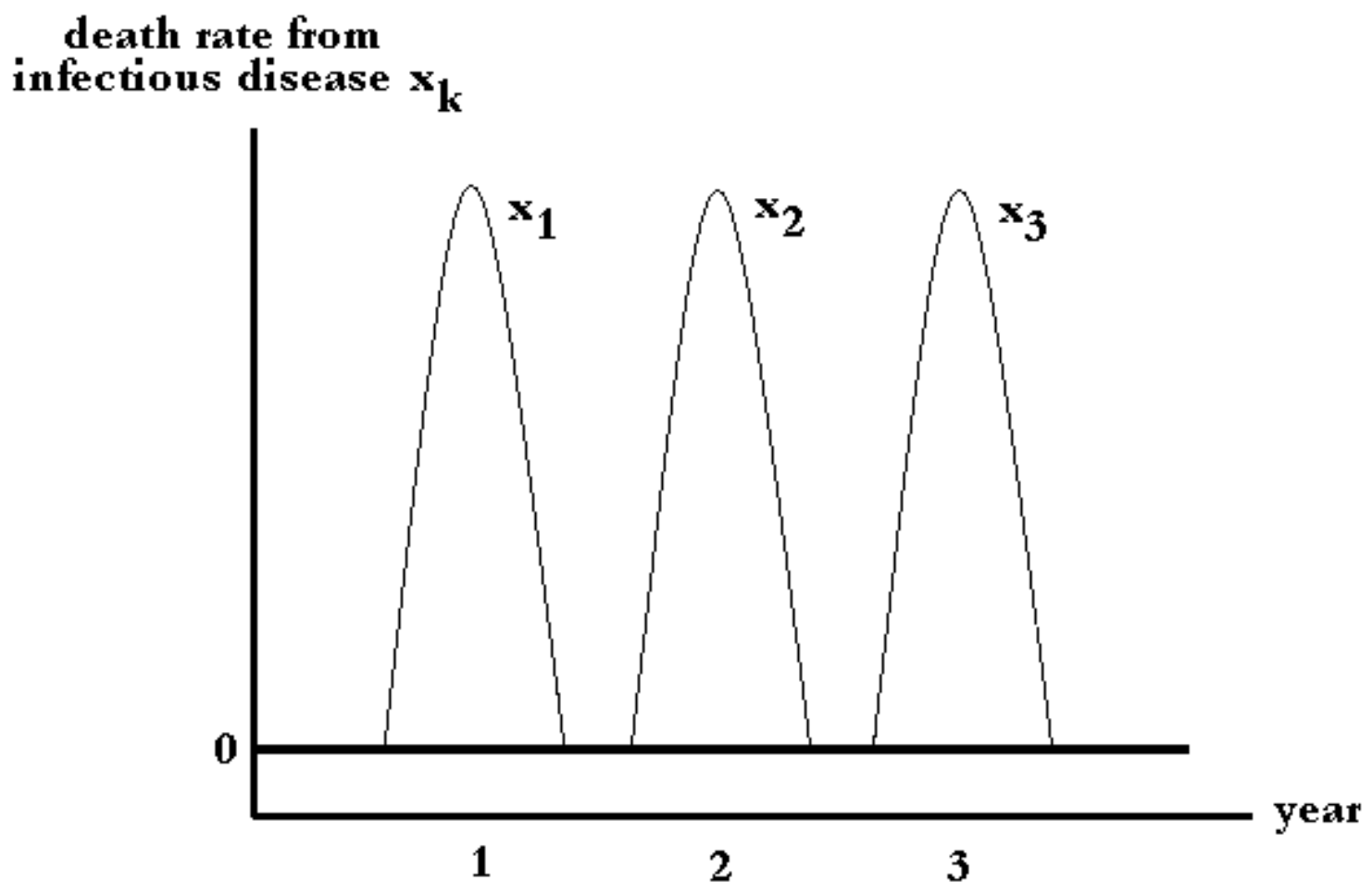

Figure 3. The Epidemic Nature of Infectious Diseases

Notes: this graph again follows birth cohort, and describes the evolution of three hypothetical infectious diseases over that same three year period. The model presented in the text assumes that infectious diseases strike in waves of epidemics so that in year 1 , disease $x_{1}$ (say typhoid) kills $x^{*}$ of the persons in the birth cohort; in year 2 disease $x_{2}$ (say influenza) kills $x^{*}$ persons in the cohort; and in year 3 disease $x_{3}$ (say whooping cough) kills $x^{*}$ persons in the cohort.

Source: see text. 


\section{death rate from \\ infectious disease $\mathbf{x}_{\mathbf{k}}$}

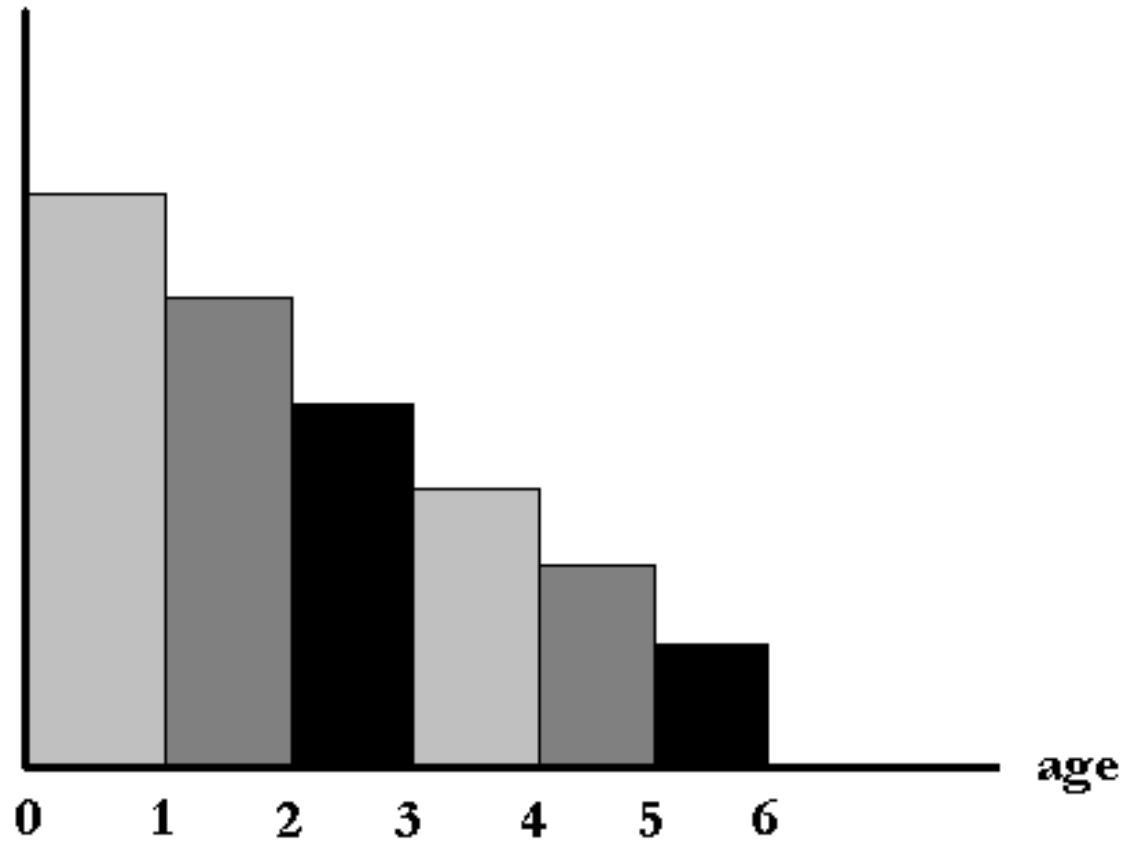

Figure 4. Age-Specific Death Rates for Infectious Disease $X_{\mathrm{k}}$

Notes: For each disease $x_{\mathrm{k}}$ considered individually, one imagines a scenario that is similar to that of lead: the youngest children are the most vulnerable. However, in contrast to lead-related deaths, exposure to a disease in the previous period has not eliminated all of the vulnerable children in older populations. Consequently, whenever the epidemic of disease $x_{\mathrm{k}}$ hits, infants will not be the only ones who die; so too will older children. A plausible age-vulnerability profile for disease-related deaths is given in figure 4. As in figure 2, the exact structure of this profile is an empirical matter. But the basic point is that, in contrast to the age-profile for lead-related deaths-which suddenly drops to zero once a child reaches some threshold in development-disease-related deaths decline slowly as one moves up age categories.

Source: see text. 


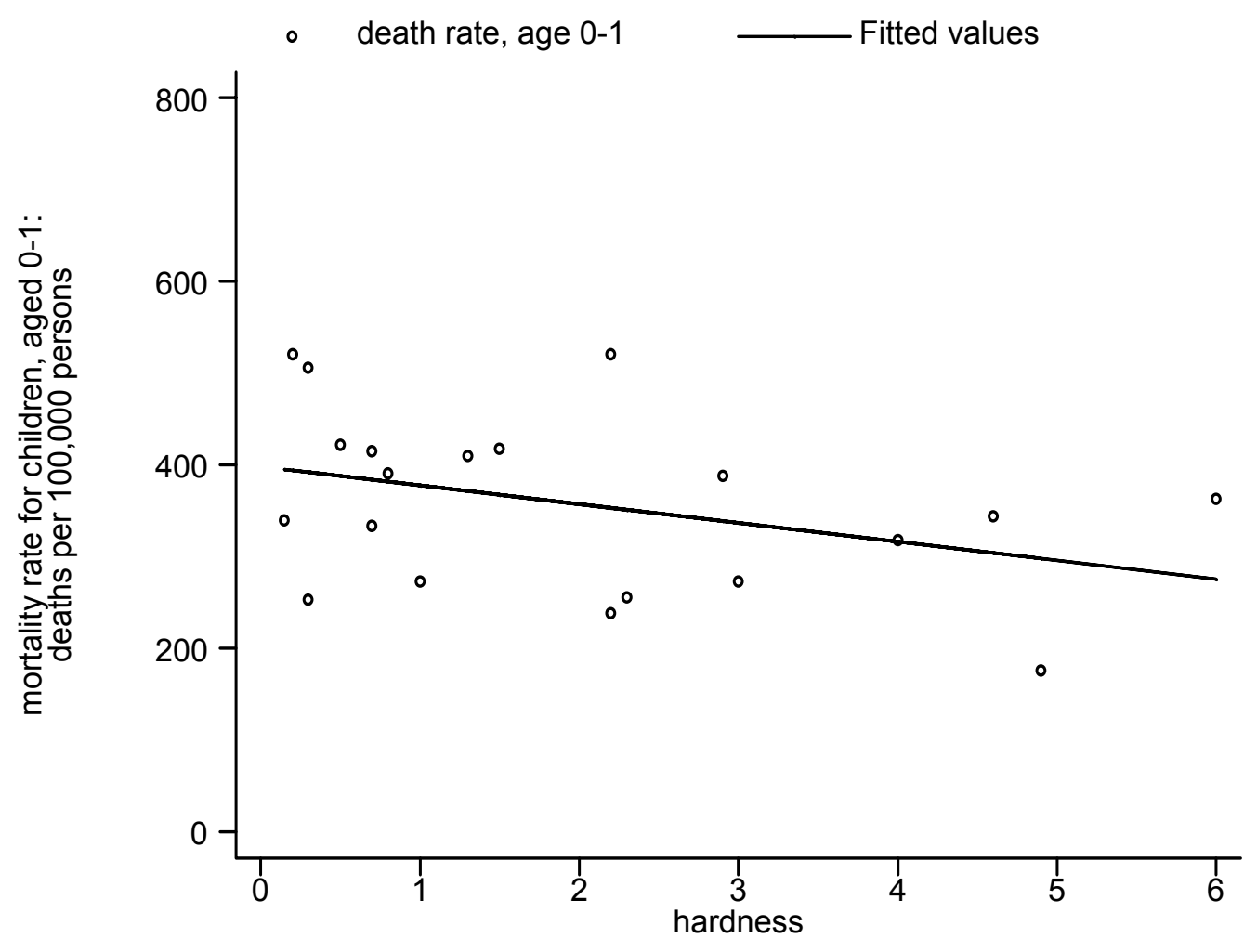

Figure 5. Water Hardness and Infant Mortality: Cities With No Lead Water Pipes

Notes: a water's hardness reflects the amount of calcium and magnesium in the water. Hard water tends to be less corrosive than soft water. For the sample of cities used in this paper, the measure of hardness varies from about 1 to 6 .

Source: see text. 


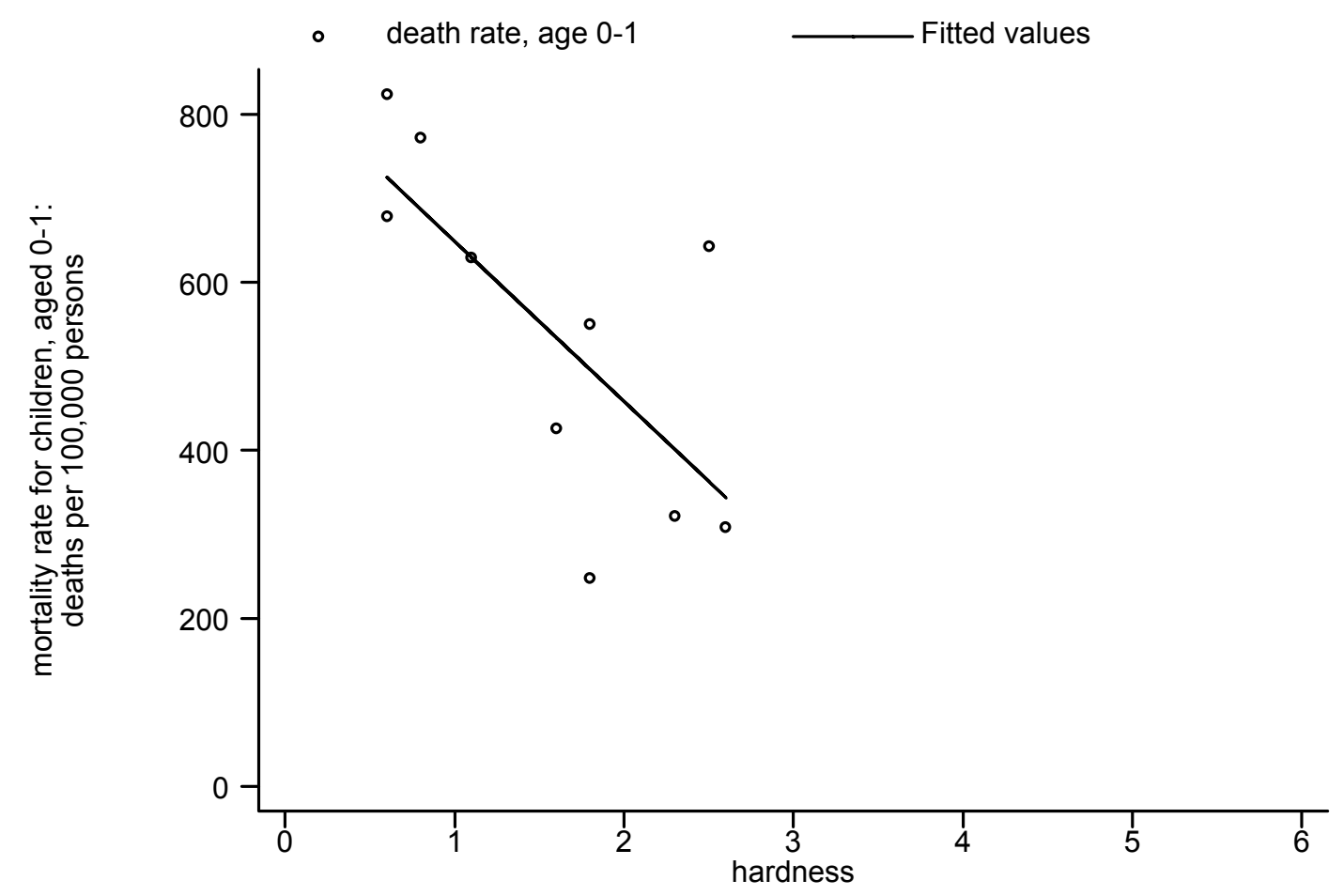

Figure 6. Water Hardness and Infant Mortality: Cities With Lead Water Pipes

Notes: a water's hardness reflects the amount of calcium and magnesium in the water. Hard water tends to be less corrosive than soft water. For the sample of cities used in this paper, the measure of hardness varies from about 1 to 6 , though for cities with lead pipes, the index of hardness never rises above 3 .

Source: see text. 


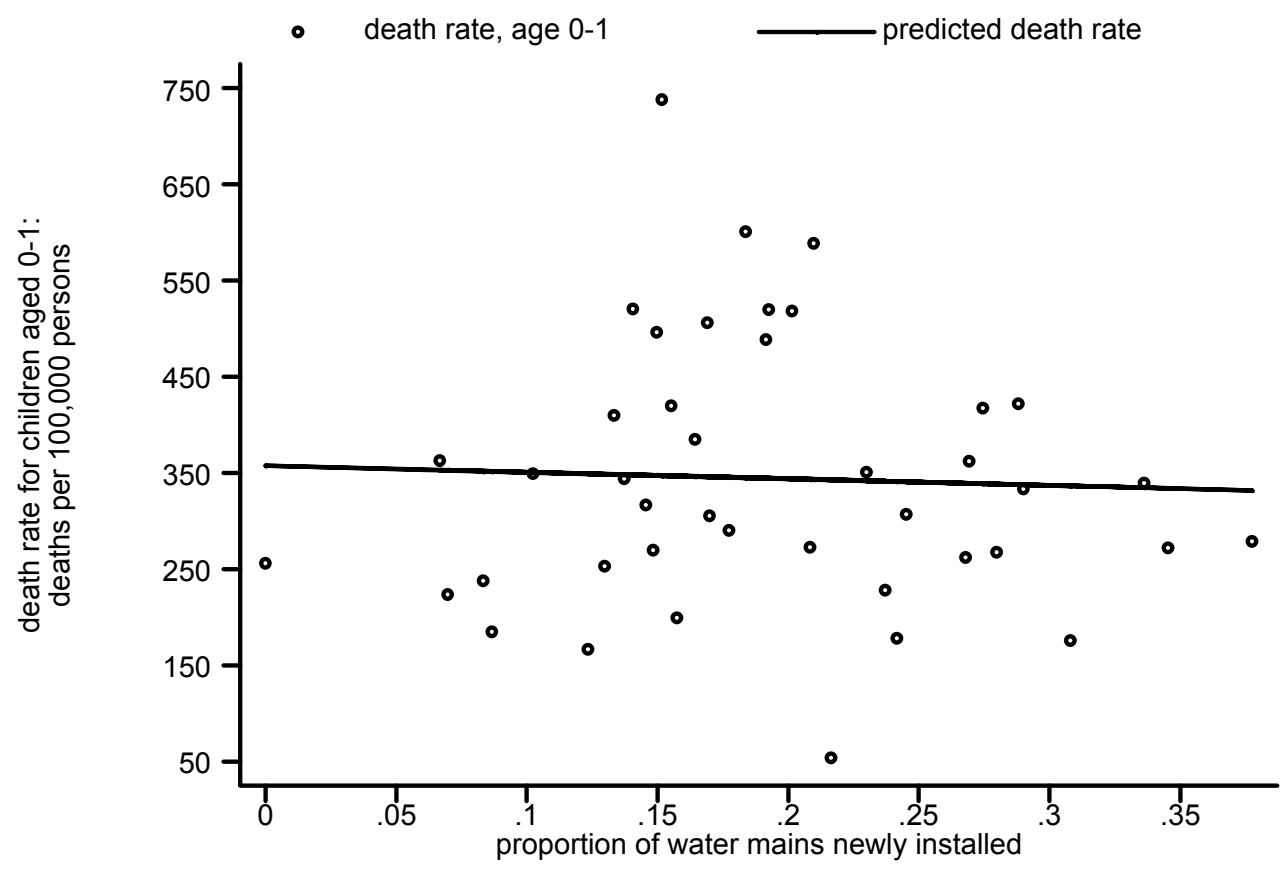

Figure 7. New Water Mains and Infant Mortality: Cities With No Lead Water Pipes

Notes: the $\mathrm{x}$ axis indicates that proportion of water mains in the town in question that have been installed during the previous ten years. Presumably, towns with many new water mains also would have had many new service pipes. More lead tends to be dissolved from the interior of new pipes than old.

Source: see text. 


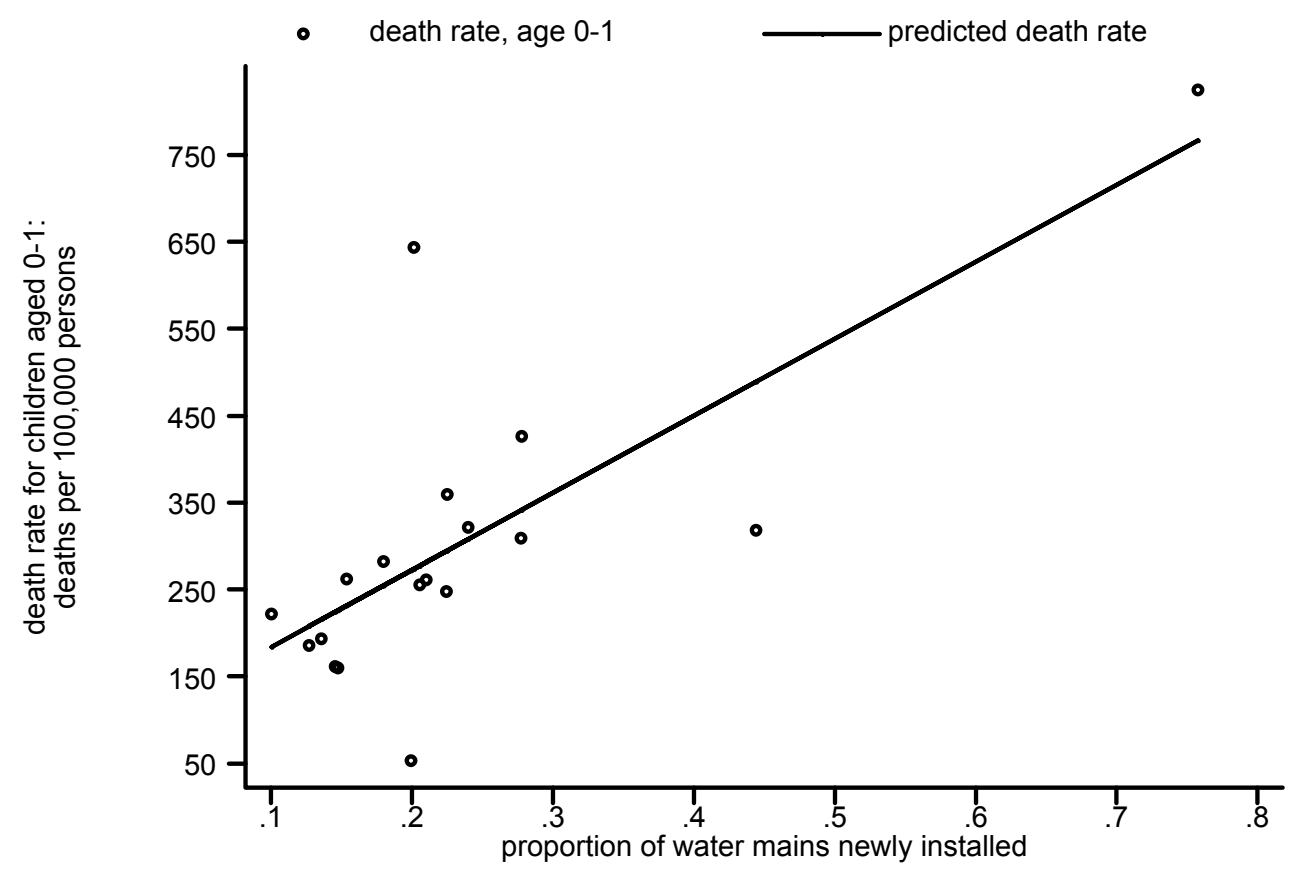

